NBER WORKING PAPER SERIES

\title{
A SURVEY OF EMPIRICAL RESEARCH ON NOMINAL EXCHANGE RATES
}

\author{
Jeffrey A. Frankel \\ Andrew K. Rose \\ Working Paper No. 4865 \\ NATIONAL BUREAU OF ECONOMIC RESEARCH \\ 1050 Massachusetts Avenue \\ Cambridge, MA 02138 \\ September 1994
}

This paper is to be a chapter in The Handbook of International Economics, edited by Gene Grossman and Kenneth Rogoff, North Holland. For comments, we thank: Michael Dooley, Charles Engel, Robert Flood, Peter Garber, Charles Goodhart, Karen Lewis, Richard Lyons, Maurice Obstfeld, Ken Rogoff, and participants at the Handbook of International Economics Conference at Princeton. This paper is part of NBER's research program in International Finance and Macroeconomics. Any opinions expressed are those of the authors and not those of the National Bureau of Economic Research.

(C) 1994 by Jeffrey A. Frankel and Andrew K. Rose. All rights reserved. Short sections of text, not to exceed two paragraphs, may be quoted without explicit permission provided that full credit, including () notice, is given to the source. 
NBER Working Paper \#4865

September 1994

\title{
A SURVEY OF EMPIRICAL RESEARCH ON NOMINAL EXCHANGE RATES
}

\begin{abstract}
We survey the empirical literature on floating nominal exchange rates over the past decade. Exchange rates are difficult to forecast at short- to medium-term horizons. There is a bit of explanatory power to monetary models such as the Dornbusch "overshooting" theory, in the form of reaction to "news" and in forecasts at long-run horizons. Nevertheless, at short horizons, a driftless random walk characterizes exchange rates better than standard models based on observable macroeconomic fundamentals. Unexplained large shocks to floating rates must then, logically, be due either to innovations in unobservable fundamentals, or to non-fundamental factors such as speculative bubbles. The observed difference in exchange rate and macroeconomic volatility under different nominal exchange rate regimes makes us skeptical of the first view. The theory and evidence on speculative bubbles, however, is not conclusive. We conclude with the hope that promising new studies of the microstructure of the foreign exchange market might eventually rise to insights into these phenomena.
\end{abstract}

Jeffrey A. Frankel Institute for International Economics 11 Dupont Circle, NW Washington, DC 20036 and NBER
Andrew K. Rose

Haas School of Business

350 Barrows Hall

University of California

Berkeley, CA 94720

and NBER 


\section{A Survey of Empirical Research on Nominal Exchange Rates Jefrrey A. Frankel and Andrew K. Rose}

\section{CONTENTS}

0 . Introduction

I. Empirical Studies of Exchange Rate Movements

\section{I.A. Overview}

I.B. Models with Fundamentals

I.B.1. Empirical Equations of Exchange Rate Determination

I.B.1.a. Flexible Prices

I.B.1.b. Sticky Prices and Overshooting

I.B.1.c. Portfolio Balance and Sterilized Intervention

1.B.2. Anticipated vs Unanticipated Effects: The News

I.B.2.a. Statistical Innovations

I.B.2.b. Announcement Effects

1.C. Forecasting

I.C.1. With Fundamentals

I.C.2. Without Fundamentals

I.D. Summary

II. Evidence from across Fixed and Floating Regimes

III. Speculative Bubbles

IV. The Micro Evidence on the Foreign Exchange Market

IV.A. The Formation of Expectations

IV.A.1. Are Expectations Stabilizing or Destabilizing: Survey Data

IV.A.2. Heterogeneous Expectations

IV.A.3. Technical Analysis

IV.A.4. Models of Chartists and Fundamentalists

IV.B. Trading

IV.B.1. The Nature of Trading

IV.B.1.a. Time-Varying Volatility, Trading Volume, and Location

IV.B.1.b. The Bid-Ask Spread, Volatility and Volume

IV.B.2. The Behavior of Market-makers

IV.C. An Early Assessment of the Market Micro-Structure Literature

V. Conclusion: Endogenous Speculative Bubbles? 


\section{Q. Introduction}

This paper is intended to be a selective critical survey and interpretation of recent exchange rate research. We focus on empirical results for exchange rates among major industrialized countries.

In the decade since the publication of the first two volumes of The Handbook of Intemational Economics, there have been three main strands of empirical research in international finance. The first and largest has been concerned with the determination of floating exchange rates; the second has addressed the issue of the efficiency of foreign exchange market efficiency and uncovered interest parity; the most recent has dealt with the characteristics of explicitly managed exchanged rates. In this chapter, we review the first topic. (The second and third chapters are covered in this Handbook in the chapters by Lewis, and Garber and Svensson, respectively.) We begin by surveying the work on exchange rate determination in floating rate regimes, and then consider evidence across exchange rate regimes. After a brief examination of the issue of speculative bubbles, our chapter finishes with a discussion of some relatively new directions in exchange rate research that focus on the micro-structure of foreign exchange markets.

\section{Floating Exchange Rates}

\section{I.A. Overview}

Most of the large industrialized economies floated their exchange rate in early 1973, after the demise of the post-war Bretton Woods system of fixed exchange rates. While there had been extensive academic disputes on the relative merits of fixed and floating exchange rates, this discussion had been carried on at a largely hypothetical 
level (and is analyzed in the chapter by Garber and Svensson). The generalized floating regime provided economists with the empirical data set required to resolve such academic disputes, as well as raising more immediate policy issues. Much of the international finance literature produced in the decade after the move to generalized floating focused on the development and estimation of empirical models of floating exchange rates.

By the early 1980 s however, some early apparent empirical successes in the literature had been overturned and key empirical findings began to turn negative, a state of affairs that continues through the present day. The most profound negative result was produced by Meese and Rogoff $(1983 \mathrm{a}, \mathrm{b})$, who compared the predictive abilities of a variety of exchange rate models. Their key result was that no existing structural exchange rate model could reliably out-predict the naive alternative of a random walk at short-and medium-run horizons, even when aided by actual future values of the regressors. This extremely negative finding has never been entirely convincingly over-turned despite many attempts. The simple random walk model of the exchange rate has become the standard benchmark for empirical exchange rate performance, no matter how uninteresting it is per se. (Indeed a number of researchers have professed to view the random walk "model" as being intrinsically interesting.)

Many of the most important empirical regularities remain what they were 15 years ago. Mussa (1979) made the following points, among others: 1) the log of the spot rate is approximately a random walk; 2) most changes in exchange rates are unexpected; 3 ) countries with high inflation rates tend to depreciate, and at approximately the inflation differential in the long run; and (4) actual exchange rate movements appear to overshoot movements in smoothly adjusting equilibrium exchange rates. The recent literature on floating rates is quite consistent with these propositions. 
Nevertheless, some progress has been made. Above and beyond the issue of the determination and prediction of floating exchange rates, there have been a number of smaller streams of research in the area. One looks across exchange rate regimes; another focuses on survey evidence of exchange rate expectations; a third promising new area is the microeconomic modelling of foreign exchange markets. One of our objectives in this chapter is to provide a road map to these areas; we survey each in turn.

There are already a number of existing surveys. MacDonald (1990) and MacDonald and Taylor (1989, 1992, 1993b) offer particularly comprehensive reviews of the literature, focussing primarily on exchange rate determination and prediction. More selective perspectives are offered by Dornbusch (1987), Boughton (1988), Kenen (1988), Mussa (1989), Meese (1990), and Krugman (1993).

\section{I.B. Models with Fundamentals}

\section{I.B.1. Empirical Equations of Exchange Rate Determination}

The standard workhorse of international finance is the monetary model of the exchange rate. The model starts with the reasonable statement that, as the exchange rate is the relative price of foreign and domestic money, it should be determined by the relative supply and demand for these moneys. The typical model stems from three equations. The first is money-market equilibrium:

$$
m_{1} \cdot p_{1}=\beta y_{1} \cdot \alpha i_{1}+\epsilon_{1}
$$

where: $m_{t}$ denotes the stock of money at time $t ; p$ denotes the price level; $y$ denotes real income (all three in natural logarithm form); i denotes the nominal interest rate; $\epsilon$ 
denotes a shock to money demand; and $\alpha$ and $\beta$ are positive structural parameters. It is traditional to assume that there is a comparable equation for the foreign country, and that domestic and foreign elasticities are equal.1/ Subtracting the foreign analog (where an asterisk denotes a foreign value) yields:

$$
\left(p-p^{*}\right)_{1}=\left(m-m^{*}\right)_{1}-\beta\left(y-y^{*}\right)_{1}+\alpha\left(i-i^{*}\right)_{1}-\left(\epsilon-\epsilon^{*}\right)_{1}
$$

\section{LB.1.a. The Monetary Model with Flexible Prices}

The other two conditions enter as different substitutions for two of the terms in this equation. One can model (and replace) the relative price term by assuming that prices are either flexible or sticky. Similarly, one can model the interest rate differential as either simply satisfying uncovered interest parity, or as incorporating some adjustment for risk. The simplest monetary model assumes flexible prices; thus, in the absence of transportation costs and other distortions, purchasing power parity (PPP) holds, at least up to a disturbance:

$$
\left(p-p^{*}\right)_{1}=e_{1}+v_{1}
$$

where e denotes the (log) spot domestic price of a unit of foreign exchange, and $v$ is a stationary disturbance. The solution for the exchange rate is then immediate:

$$
e_{1}=\left(m-m^{*}\right)_{t}-\beta\left(y-y^{*}\right)_{1}+\alpha\left(i-i^{*}\right)_{1}-\left(\epsilon-\epsilon^{*}\right)_{1}-v_{t} .
$$

1/ Though Haynes and Stone (1981) object to this practice. 
Finally, it is typically assumed that domestic and foreign assets are perfect substitutes, except possibly for an exogenously-varying time premium, so that the interest rate differential equals the expected depreciation rate plus a possible risk premium $\rho_{\text {r }}$. Thus a modified form of uncovered interest parity [UIP] holds:

$$
(i-i *)_{t}-\rho_{t}=E_{t}\left(d e_{t}\right) / d t
$$

where $E_{1}$ denotes the expectations operator conditional on information available at time t. The simple flexible-price monetary "fundamental" can be defined as:

$$
f_{1} \equiv\left(m-m^{*}\right)_{1}-\beta\left(y-y^{*}\right)_{t}-\left(\epsilon-\epsilon^{*}\right)_{t}-v_{t}+\rho_{t} .
$$

Substituting in the modified UIP condition, the exchange rate equation then becomes:

$$
e_{i}=f_{t}+\alpha E_{1}\left(d e_{1}\right) / d t
$$

This expression was first derived by Mussa (1976). A very similar equation can be derived from the currency substitution model (e.g., Calvo and Rodriguez, 1979). Stockman (1980) and Lucas (1982) gave the simple monetary model more respectability by replacing the ad hoc money demand equations with money-in-theutility-function and cash-in-advance assumptions, respectively. Early and influential empirical studies included Frenkel (1976, 1978), Bilson (1978), and Hodrick (1978) and other papers gathered in Frenkel and Johnson (1978).

After initial claims of success, the empirical failures of the simple monetary model became swiftly apparent. The coefficient estimates (of $\alpha$ and $\beta$ ) and empirical fit of such models were never particularly good, except perhaps under hyperinflation 
conditions. Also, high volatility of real exchange rates, and the highly positive correlation of nominal and real exchange rates, became obvious enough to warrant explicit treatment. Finally, the models turned out to forecast poorly out-of-sample.

Some of these problems can be easily illustrated using actual data. Figure 1 contains time-series plots of bilateral Japanese/American data from 1960 though 1992; Figure 2 has the analogs for the UK vis-a-vis Germany. Each figure portrays three variables: the nominal exchange rate (graphed with a thin solid line); the real exchange rate (graphed with plus marks); and "monetary fundamentals" (graphed with small circles). The real exchange rate is the nominal exchange rate adjusted using Consumer Price Indices; monetary fundamentals are a (scaled) standard measure of flexible-price monetary fundamentals, namely the ratios of domestic and foreign money supplies over the ratio of domestic and foreign levels of real output (that is, $\left[\left(M_{U K} / M_{G}\right) /\left(Y_{U K} / Y_{G}\right)\right]$ for the British-German case, and analogously for the Japanese-U.S. case, where capital letters denote the levels of the variables).

The graphs show a number of features which are pervasive in bilateral data. First, both the nominal exchange rate and fundamentals appear to be non-stationary, though the real exchange rate does not (except perhaps for a trend in the real yen/dollar rate). Second is the important comparison across regimes. Nominal exchange rates were fixed explicitly at the beginning of the sample under the Bretion Woods regime, and the pound-mark rate was also stabilized during the period 1990-92, when Britain was in the Exchange Rate Mechanism of the European Monetary System. In each case (1960-72 for the yen/dollar rate in Figure 1, and 1960-69 and 1990-92 for the pound/mark rate in Figure 2), nominal exchange rate stabilization is reflected in a corresponding stabilization of the real exchange rate, but surprisingly did not require a corresponding stabilization in macroeconomic fundamentals. 


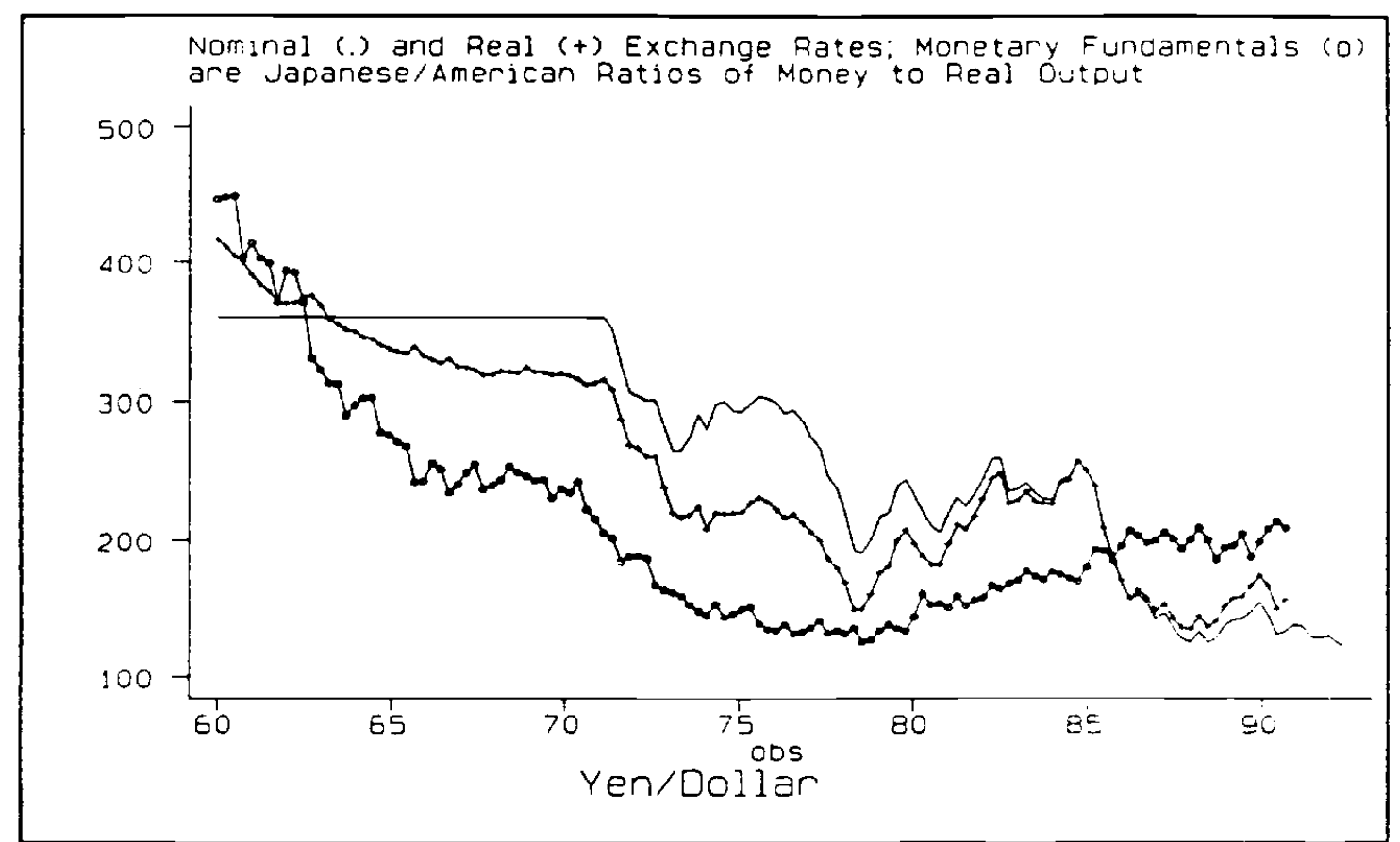

Figure 1

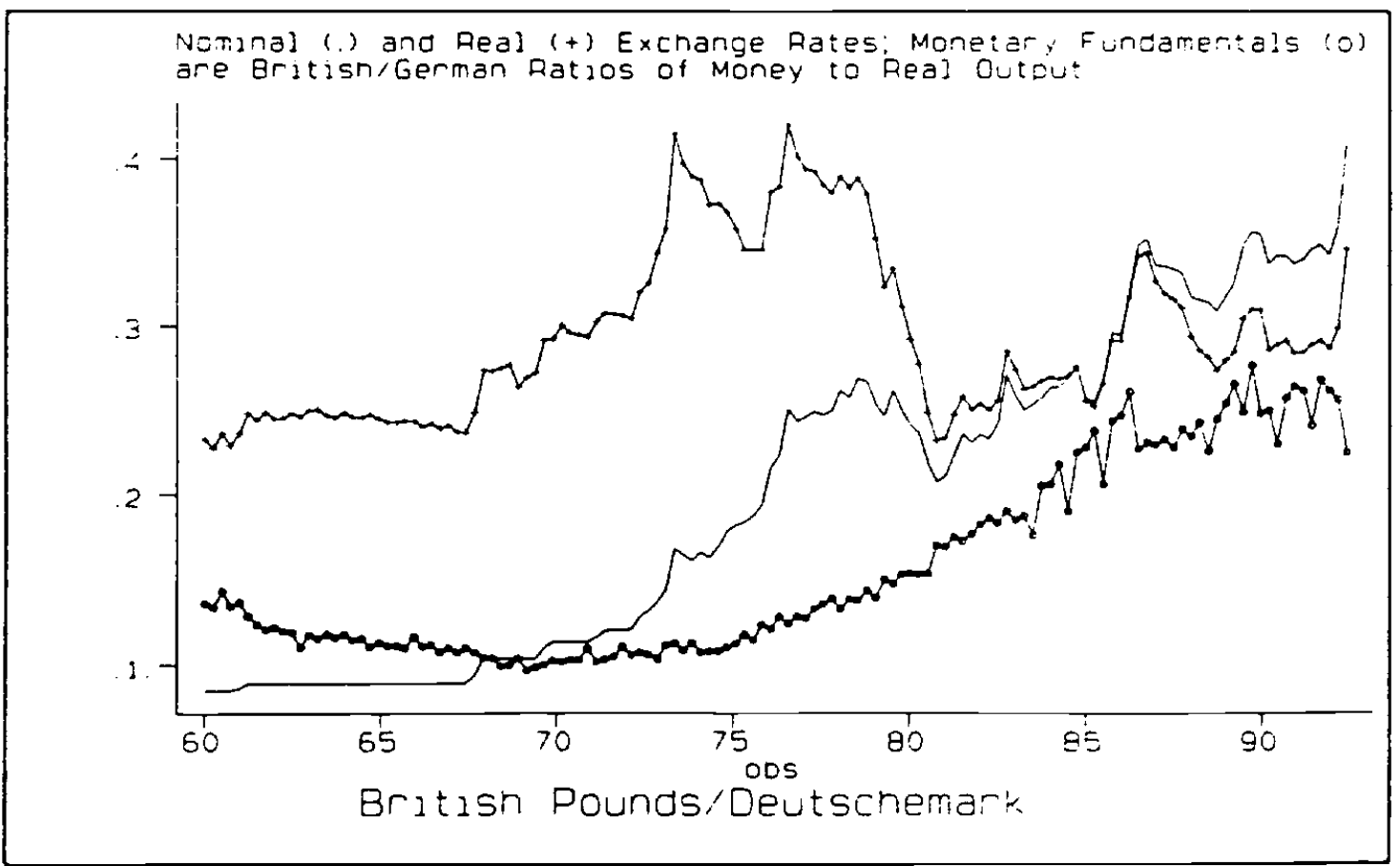

Figure 2 
A third stylized fact is that the relationship between the monetary fundamentals and the nominal exchange rate does not appear to be close in the short-run, though they may share longer-run trends. Given that both sets of data are typical for industrialized countries, the finding of poor coefficient estimates and goodness-of-fit in flexible-price monetary models is unsurprising. Finally, the correlation between nominal and real exchange rates is considerable at high frequencies, though it appears to fall at lower frequencies. This apparent contradiction to the assumption of flexible prices leads naturally to the subject of price stickiness.

\section{L.B.1.b. Price Stickiness and Overshooting}

An alternative to making the PPP assumption is explicitly to model goods-market prices as being sticky, at least in the short run. The classic theoretical paper was Dornbusch's (1976b) contribution which demonstrated that in the short run, nominal exchange rates may "overshoot" their long-run levels.1/ This was followed by Frankel (1979), Mussa (1979), and Buiter and Miller (1982).2/ Price-stickiness can be easily incorporated into the empirical structural models of exchange rates.

A simple, yet strong, statement that captures the essence of the Dornbusch model is a statement of proportionality between the real exchange rate and the contemporaneous real interest differential. Start by subtracting expectations of the inflation differential from the statement of uncovered interest parity:

1) Forerunners included Mundell (1964), Niehans (1975) and Dornbusch (1976a).

2) Extensions, such as full system estimation with an allowance for cross-equation constraints, included Driskill (1981), Driskill, Mark and Sheffrin (1992) and Papell $(1988,1989,1993)$. 


$$
\left(i-i^{*}\right)_{1}-E_{t}\left(d p_{t}-d p^{*}\right)=E_{i}\left(d e_{t}\right) / d t-E_{t}\left(d p_{t}-d p^{*}\right)+\rho_{t}
$$

or

$$
r_{t} \cdot r^{*}{ }_{t}=E_{t}\left(d q_{t}\right) / d t+\rho_{t}
$$

where: $r_{1}$ and $r *$ are the ex ante expected real interest rates, defined by $r_{1}=i_{1}-E_{1}\left(p_{1+1}-\right.$ $\left.p_{t}\right)$, and $q_{1}$ is the real exchange rate, defined as $e_{t}-p_{t}+p^{*}$. Equation (8) states that for both countries' assets to be willingly held, a difference in real interest rates across countries must be matched by an expectation of real depreciation.

A second assumption used is that the real exchange rate is expected to revert toward a long run equilibrium value, $\bar{q}_{1}$.

$$
E_{i}\left(d q_{1}\right) / d t=-\theta\left(q_{t}-\bar{q}_{t}\right)
$$

Combining equations and solving, we obtain a proportionality between the level of the real exchange rate and the real interest differential:1/

$q_{t}-\bar{q}_{1}=-(1 / \theta)\left[\left(i-i^{*}\right)_{t}-E_{1}\left(d p_{t}-d p^{*}\right)\right]+\rho_{t}=-(1 / \theta)\left[r_{t}-r^{*} t\right]+\rho_{t}$

Recent tests have focused on this equation per se.

1/ Initially, attention focused on short-term real interest rates (e.g., Frankel, 1979). Short-term rates are implicit in equation (10) here, as is appropriate if the expected regression of the real exchange rate in equation (9) is assumed to follow a first-order autoregressive process, which in turn is the rational expectation if price adjustment follows a first-order autoregressive process. An alternative approach using long-term differentials was inaugurated by Isard (1983). Assume a version of equation (9) in which some long span of time, say $1 /$ years, is considered sufficiently long for $q_{t}$ to return to equilibrium (with no position taleen on the specific time path). If such an equation is combined with a version of equation (8) expressed with correspondingly long-term interest rates, the result is a version of equation (10) suitable for use with real interest rates of term $1 /$. 
Early tests of the overshooting model tended to focus on models more like Dornbusch (1976), that is, fleshed out in a form more complete than the simple proportionality between the real exchange rate and the real interest differential. The more complete model allows for price stickiness in a standard way. Substitute a Phillips-curve equation where the flexible-price model assumed continuous purchasing power:

$$
\begin{aligned}
& p_{1+1}-p_{t}=\mu\left(y-y^{L R}\right)_{t}+g_{t}+E_{t}\left(\hat{p}_{t+1}-\hat{p}_{t}\right) \\
& y_{1}-y^{L R}=\gamma+\theta^{\prime}(q)_{t}+\phi^{\prime} r_{1} \\
\Rightarrow> & p_{1+1}-p_{t}=\theta(q)_{t}+\phi r_{t}+g_{t}+E_{t}\left(\hat{p}_{t+1}-\hat{p}_{t}\right)
\end{aligned}
$$

where: $y^{L R}$ is the long-run level of output; $g$ is a well-behaved shock to goods market equilibrium; and $\hat{\mathrm{p}}_{\mathrm{t}}$ is defined as the price level that would prevail at time $t$ if prices were flexible and goods markets cleared:1/

$$
\theta\left(e+p^{*}-\hat{p}\right)_{1}+\phi r_{1}+g_{1}=0 .
$$

Equation (11) gives the system its long-run equilibrium $\left(\bar{q}_{1}\right)$, and its dynamics (which are correctly incorporated in $\theta$, if investors are rational). Substituting equation (10) and conventional money demand functions like equation (1) yields a complete equation of exchange rate determination. This is essentially the flexible-price monetary model with the addition of extra terms representing the real interest differential, the risk premium $\rho_{1}$ [if any] and variation in the long-run equilibrium exchange rate $\bar{q}_{1}$ [if

1/ Obstfeld and Rogoff (1984) and Engel and Frankel (1984b) provide a detailed discussion of the $\hat{p}$ term. 
any]. These extra terms can be measured in a variety of ways, allowing for estimation of the exchange rate equation.

At first, empirical tests of exchange rate models with price stickiness met with success, particularly for the mark/dollar rate.1/ Subsequently, however, results began to fall apart, even in-sample: e.g., Frankel (1983a, b) and Backus (1984). More importantly, the models caved in to the same Meese and Rogoff onslaught that effectively did in the flexible-price models (i.e., unsuccessful tests of out-of-sample predictive performance).

Recent research has focused on equation (10) -- the simple testable implication of the model relating the real exchange rate to the contemporaneous real interest differential -- using increasingly sophisticated time-series econometrics. The third in the series of papers by Meese and Rogoff (1988) used the Engle-Granger test for cointegration, and failed to find evidence of such a relationship. Similarly, Campbell and Clarida (1987) found that very little of the variation in the real exchange rate could be explained by variation in the real interest differential. Many authors have noted that a possible reason for such results is the existence of a missing variable, which would enter as a determinant of either a time-varying long-run real exchange rate or a risk premium. Another possibility is weak power in the tests, since failure to find statistically significant evidence of co-integration never entitles one to claim that such a relationship does not exist.

A number of subsequent studies have used increasingly powerful econometric firepower (e.g., the Johansen procedure), and have also included other variables. Blundell-Wignall and Browne (1991) find evidence of co-integration between the real exchange rate and real interest differential when a measure of the cumulated current

1/ E.g., Frankel (1979). 
account is included; Edison and Pauls (1992) find less evidence. Throop (1992) claims strong results, including out-of-sample predictive ability, when allowing for several other variables: a lagged effect of the real interest differential, the budget deficit, the real price of oil, and a measure of the relative price of non-traded goods. Baxter (1994) finds evidence of a relationship between real exchange rates and real interest rates by looking at lower-frequency data than earlier studies.

\section{I.B.1.c. Portfolio Balance Models and Sterilized Intervention}

The portfolio-balance model is a third approach to modelling exchange rates, beyond the flexible-price and sticky-price monetary models. Tobin's portfolio-balance model was internationalized by Kouri (1976), Branson (1977), Girton and Henderson (1977) and Allen and Kenen (1980), among others. The literature was ably surveyed by Branson and Henderson (1985).

Relative to the monetary models of exchange rate determination, the key modification made by the portfolio-balance theorists is the assumption that domestic and foreign securities are not perfect substitutes. The result is that a risk premium intrudes on the uncovered interest parity condition, and supplies of bonds and other non-monetary assets intrude on the equation of exchange rate determination. The exchange rate is determined by the supply and demand for all foreign and domestic assets, not just the supply and demand for money as in the monetary approach. The resulting models are of particular use when one wants to consider the possible effects of sterilized intervention by the monetary authorities or of current account imbalances. Intervention represents a change in the supplies of assets, and thus in the protfolio balance model works to change the exchange rate accordingly: a purchase of foreign assets drives up the price of foreign exchange. In the "small-country portfolio-balance model" where international capital flows are assumed to be denominated solely in 
foreign currency, current account balances represent a change in asset supplies. A surplus raises the supply of foreign assets and thus reduces their price, which is an appreciation of the domestic currency. In more realistic models where the portfolio behavior of both domestic and foreign residents is relevant for market equilibrium, current account balances represent a change in asset demands, if the foreigners have a preference for their own assets. A surplus raises the net wealth-weighted worldwide demand for domestic assets, and thus again leads to an appreciation of the domestic currency.

Early empirical tests of the portfolio-balance model, such as Branson, Halttunen and Masson (1977, 1979), were not particularly successful, even in-sample. The outlook did not much improve when researchers did a more careful job of measuring asset supplies (e.g., Frankel (1983b), Backus (1984), and Golub (1989) ).

This line of research took a new direction in the 1980s. Early work had modelled international asset demands as arbitrary functions of expected returns. Subsequently, portfolio-balance modelers made the assumption that investors diversified their portfolios optimally, in the manner dictated by expected utility maximization. A typical implication in these models was that the degree of substitutability between domestic and foreign assets depended inversely on the degree of risk-aversion and the exchange rate variance (or variance-covariance matrix, when there are more than two currencies in the portfolio). The relevant empirical tests are surveyed in the chapter by Lewis in this volume.1/

As noted, one of the major motivations for considering the portfolio-balance approach is that it enables one to consider the possible effects of sterilized intervention, that is, intervention that is not allowed to affect money supplies, and thus

1/ E.g.: Frankel (1982), Black and Salemi (1988), Lewis (1988), and Engel and Rodriguez (1989). 
has no effect on the fundamentals dictated by monetary exchange rate models. Several studies published in the aftermath of the 1983 Jurgensen Report by research departments of $\mathrm{G} .7$ central banks on intervention surveyed the empirical literature that existed at that time (Tryon (1983), Henderson (1984), Henderson and Simpson (1983), and Henderson, Danker, Haas, Symansky, Tryon (1987).) The early studies mostly consisted of various tests of the portfolio-balance model, using quarterly data on asset supplies. Estimated effects were generally small and statistically insignificant, if even of the correct sign. This was especially true when the quantity of intervention was calculated in the theoretically correct fashion (i.e., cumulative, combined with government deficits and any other components of the net supplies of assets denominated in the currencies in question).1/

Several developments reinvigorated this subject of research toward the end of the 1980s: the advent of the "signaling" hypothesis, the increased availability of daily data, and the widely perceived success of concerted intervention by the G-7 in the period beginning with the 1985 Plaza Agreement to bring down the value of the dollar. Studies such as Dominguez $(1990,1992)$ seemed to show an effect when actual daily intervention data were used. The more recent literature has been comprehensively and ably surveyed by Edison (1993).

The current conventional wisdom (e.g., Obstfeld 1990) is that -- precisely because international financial markets are well-developed, highly integrated, and subject to diversification -. central bank purchases or sales of foreign exchange are unlikely to be large enough to have much of an effect on the exchange rate. The possible exception is non-sterilized intervention that affects money supplies. If the effect is

1/ E.g., Dooley and Isard (1982a, 1983), Frankel (1982) or Rogoff (1984). 
contemporaneous, it is simply a variety of monetary policy. However, the effects on future money also matter. Some years ago Mussa (1981), among others, suggested the "signaling" hypothesis: sterilized intervention may be effective if it signals future changes in monetary policy. This channel requires, first, that intervention is reported to market participants, and second that they interpret it as conveying information on future monetary policy that is actually validated on average by the monetary authorities. Klein (1993) offers evidence relevant to the first proposition; Kaminsky and Lewis (1993), Klein and Rosengren (1991) and Lewis (1990, 1993) offer much more ambiguous evidence relevant to the second. Dominguez and Frankel $(1993 \mathrm{a}, \mathrm{b})$ have found evidence of intervention effects through both the signaling channel and the traditional portfolio channel.1/ Catte, Galli, and Rebecchini (1994) and Eijffinger and Gruijters (1991) claim even stronger evidence of effects of daily intervention.

A persuasive, but less-noticed, train of thought within the portfolio-balance model has been pursued by Dooley and Isard (1982b, 1987, 1991), as well as Krugman (1985) and Bovenberg (1989), who view the cumulated current account deficit as an important determinant of the exchange rate because political risk puts a limit on the extent to which international investors wish to lend to a particular country, rather than because exchange risk puts a limit on the extent to which investors wish to hold assets denominated in a particular currency. Dooley, Isard and Taylor (1993) claim some supporting empirical findings.

\section{B.2. Anticipated vs Unanticipated Effects: The "News"}

1/ Dominguez and Frankel (1993a, b) use survey data to measure investors' expectations, as discussed in Part $\mathrm{V}$ below, and newspaper accounts to distinguish between public reports of intervention and true intervention. 
Volatility of foreign exchange rates is considered to be sufficiently high to be worthy of study by applied researchers. Standard asset-pricing models rationalize volatility in terms of revisions regarding expectations of future developments arising out of new information, that is, in terms of "news". In this sub-section, we review recent developments in this literature.

From the time when expectations were first introduced into the asset-market approach to exchange rate determination,1/ it has been recognized that unexpected events have a qualitatively different effect on the exchange rate from anticipated developments. Specifically, the exchange rate should change discontinuously in response to new pieces of unanticipated relevant information, and not otherwise. Anticipated discrete changes are ruled out, since they would represent an unexploited profit opportunity. Only gradual changes are possible in the absence of news. Such gradual changes can occur, for example, in step with the price level or the stock of foreign assets, which typically move gradually over time.2/ (For the time being, we are ruling out speculative bubbles and the bursting thereof, which would constitute a sudden change without an exogenous cause. They are considered in further below.)

\section{I.B.2.a. Statistical Innovations}

Dornbusch (1978; 1980, pp.157-163) and Frenkel (1981, pp.686-693) suggested the term "news" to call attention to the sort of unanticipated developments that should affect the exchange rate discretely. Their empirical work used statistical innovations (from ARIMA processes) in interest differentials and other mactoeconomic variables

1/ Black (1973) was an early introduction of rational expectations.

2/ Obstfeld and Stockman (1985) provide a survey. For the efficient markets hypothesis to hold, gradual appreciation or depreciation must be offset by sufficient differences in interest rates, so that domestic and foreign assets are equally attractive at the margin. 
to model expectations and thereby derive measures of news.1/ This approach tends to produce more significant effects on the exchange rate than using similar macroeconomic variables that have not been converted to statistical innovations. Dornbusch found that unexpected current account improvements result in dollar appreciations, as did Branson (1983) in a VAR study motivated by the portfoliobalance model. Dornbusch found that business cycle effects were also of the right sign, but insignificant. The money supply effects were mixed. Edwards $(1982,1983)$ found positive effects of innovations in the domestic/foreign money supply ratio on the price of foreign exchange, as would be predicted by most monetary models. MacDonald (1983), however, found that an unanticipated increase in the German money supply led to an appreciation of the Deutschemark, suggesting anticipations of future tightening.

To distinguish between the flexible-price and sticky-price versions of monetary models, one can look at interest rate innovations. On the one hand. Frenkel found positive effects of innovations in interest rates on the price of foreign exchange, suggesting that they capture inflation expectations, as called for in his flexible-price monetarist model. Copeland (1989, p.225), on the other hand, found that an unanticipated increase in the German interest rate led to an appreciation of the Deutschemark.

More recently, Eichenbaum and Evans (1993) have sought to isolate changes in the U.S. money policy that can be specifically identified as unanticipated, exogenous, or deliberate, using three alternative methods: statistical innovations in a measure of nonborrowed reserves; innovations in the federal funds rate; and deliberate policy shifts recorded from history using the minutes of the Federal Reserve's Open Market Committee. They find similar results with all three measures: monetary contractions

1/ For current account balances and business cycle developments, Dombusch used deviations from OECD forecasts. 
lead to dollar appreciations. At the same time, there are also positive effects on interest rates, suggesting to Eichenbaum and Evans a rejection of the popular real business cycle model (the modern successor to the flexible-price monetary model), and support for a "liquidity effect" as in the overshooting model. The surprising aspect of their findings is that, in violation of rational expectations, there is a two-year lag before the peak effect is felt in the market. Grilli and Roubini (1993) have recently extended the Eichenbaum-Evans approach to include monetary policy in other major industrialized countries. Clarida and Galli (1994) undertake a VAR decomposition of exchange rate variation into nominal shocks and real shocks. They interpret the results as consistent with the Eichenbaum-Evans finding, and therefore with the sticky-price textbook model [albeit with lags]. However, it should be stressed that the EichenbaumEvans results have not yet been subjected to a thorough sensitivity analysis (e.g., out-ofsample forecasting tests).

Even though the Dornbusch-Frenkel approach of using fundamentals that have been converted to statistical innovations tends to produce more satisfactory results than the earlier studies, the improvement is distinctly limited. In the first place, market anticipations are not measured accurately. To use an ARIMA or VAR process as a measure of what agents expect, is to ascribe to them simultaneously not enough information, and too much. It does not ascribe to them enough information, because it leaves out all the thousands of bits of information that market investors use, beyond a few simple macroeconomic times series. It ascribes to them too much information (even under the assumption that agents are rational and thus use all available information), because it assumes that they know the parameters of the statistical process from the beginning of the sample period. A second problem with early implementations of the methodology is that they typically measure the news with final money supply numbers after revisions by govemment agencies, ignoring that these are not 
generally the same as numbers first announced, and that even first announcements generally take place days, weeks, or months after the period to which they pertain.

\section{L.B.2.b. Announcement Effects}

Both of the measurement problems inherent in the statistical approach can be solved, albeit not without work. By compiling actual announcements of official statistics from press releases, wire service stories, or newspapers, one can measure information as it actually becomes available to the market.1/ One major advantage of such announcement data is that one can pinpoint the day, and often the time of day, when the announcement was made. One can then observe the exchange rate immediately before and after the announcement, to see the effect. The advantage of such precise timing is that one can hope to isolate the impact of one particular bit of information. Empirical results show that effects typically diffuse rapidly in a stream of other information that the researcher is not able to observe, so that statistical significance disappears when exchange rate changes are measured a day or two late, let alone over months (as in standard tests of exchange rate determination). By seeking to isolate the impact of the announcement, one might hope to explain a large fraction of the variation in the exchange rate over short intervals. However, in practice, even when the effects are highly significant statistically, the goodness-of-fit statistics are usually disappointing.

The use of data from surveys on the forecasts of market participants is a way of addressing the problem that agents form their expectations based on a far wider set of data than anything the econometrician can ever hope to measure. The survey data have become a standard basis from which to measure the unanticipated component of announcements; Money Market Services, International ("MMS") provides the most

1/ The analogous stock-market tests are called event studies. 
popular survey. The timing of the MMS surveys is almost perfect for research purposes, since MMS and other financial services collect their surveys in order to see what market participants expect the datum in question to be, typically a couple of days before the scheduled announcement date. The use of survey data is discussed at greater length in Part IV below.

Engel and Frankel (1984a) examined the reaction of the mark/dollar rate to announcements regarding the preceding week's M1 in the early 1980s. Positive U.S. money surprises were associated with appreciations of the dollar at the same time that they were associated with increases in interest rates, leading the authors to conclude that: 1) during this period the Federal Reserve was expected to correct any deviations of the money supply from its target path; and 2) expectations of monetary contraction tend to raise real interest rates and cause the currency to appreciate, as in the Dornbusch overshooting model. Cornell (1982), Frankel and Hardouvelis (1985), and Tandon and Urich (1987) found the same patterns in other exchange rates: U.S. money surprises are followed by significant changes in the U.S. interest rate that are negatively correlated with the price of foreign exchange.

Ito and Roley (1987) looked at the reactions in the yen/dollar rate both to macroeconomic announcements in the United States and to those in Japan. They found that U.S. money announcements had the greatest effect.

The money announcements lost much of their impact later in the 1980s, after the Fed began to put less emphasis on its M1 targets. A number of authors have found strong announcement effects for other variables, however. Hardouvelis (1988) finds significant dollar appreciations associated with news of increases in the trade balance, decreases in inflation, and improvements in the business cycle.1/ A general pattern

1/ Hogan, Melvin, and Roberts (1991) find the same trade balance effect. 
throughout is that the reaction in the price of foreign exchange is in the opposite direction as the reaction in interest rates, which tends to support the view that these are changes in real interest rates, and that they work on the exchange rate in the manner of the Dornbusch overshooting model. Beck (1993) finds that government announcements of unexpectedly large budget deficits cause the dollar to appreciate against foreign currencies, and argues that this is evidence against debt neutrality, and in favor of the Dornbusch overshooting model.

\section{L.C. Forecast Analysis}

Fitting exchange rates to contemporary observable variables, in-sample, is one thing. Forecasting out of sample is quite another, as many applied researchers have found.

\section{C.1. Forecasting with Fundamentals}

In a now-classic study, Meese and Rogoff (1983a) compared the out-of-sample forecast precision of a variety of different exchange rate models. Using monthly data for three bilateral dollar exchange rates (as well as an effective dollar exchange rate), Meese and Rogoff compared forecasting performance by both structural and nonstructural exchange rate models, as well as by contemporaneous spot and forward rates. The non-structural models included both univariate models and vector-autoregressions. The structural models included variants of both flexible- and sticky-price monetary models. It had been widely recognized (e.g., Meese and Singleton (1982)) that exchange rates could in some sense be modelled well by an autoregression with one unit root. But Meese and Rogoff $(1983 \mathrm{a}, \mathrm{b})$ showed the important result that a simple martingale process forecasts as well as more complex structural models -- up to a year 
in advance -- even providing to the structural models ex post information on future fundamentals such as money and output. Meese and Rogoff (1983a) found these results using a variety of different estimation techniques. They corroborated their results in Meese and Rogoff (1983b) using grid-search techniques in place of actual estimation, a procedure that is immune to the usual endemic estimation problems such as simultaneity bias. Their work permanently shifted the focus of empirical exchange rate work from in-sample fitting to prediction analysis.

Some authors have pursued more sophisticated econometric estimation techniques in attempts to overturn such results. For instance, Meese and Rose (1991) used a variety of non-linear and non-parametric techniques in the context of structural exchange rate models. They found little evidence of either "time-deformation" or significant non-linearities in the functional forms linking exchange rates to fundamentals which could explain the poor performance of linear exchange rate models.

Not all performance tests on structural exchange rate models have come out completely negative. Woo (1985) estimated a flexible-price version of the monetary model for the dollar-deutschemark and found that the model worked well in the sense that maximum likelihood estimation lead to plausible and stable parameter estimates which did not reject tests of cross-equation restrictions and which out-forecast a random walk model a year ahead. The use of a lagged endogenous variable was crucial; Woo justifies it by appealing to slow adjustment of money demand. Similarly, Somanath (1986) also found that a monetary model with a lagged endogenous variable forecasts better than either a monetary model by itself or the lagged endogenous variable by itself (i.e., better than the random walk). Finn (1986), and MacDonald and Taylor (1993a, 1994) also claimed some predictive power for the monetary model. Schinasi and Swamy (1989) found that the sticky-price monetary model outperforms the 
random walk when allowance is made for both a lagged endogenous variable and timevarying coefficients. (Related results are reported in Wolff, 1987.)

A number of authors have found that structural models appear to dominate the random walk's forecasting ability at relatively long prediction horizons, a result consistent with the visual impression of common trends in exchange rates and fundamentals given by figures 1 and 2. They include Meese and Rogoff (1983b); Mark (1992); Chinn (1992); and Chinn and Meese (1992). However, the Meese and Rogoff analysis at short horizons has never been convincingly overturned or explained. It continues to exert a pessimistic effect on the field of empirical exchange rate modelling in particular and international finance in general.

\section{I.C.2. Forecasting without Fundamentals}

The triumph at short and medium horizons of the naive random-walk "model" of exchange rates (if only by default) over fundamental-based models, first discovered by Meese and Rogoff, lead to a burst of research on the univariate characteristics of nominal exchange rates. It still remains distressing that a model as simplistic as a martingale appears to perform empirically as well as extremely sophisticated alternatives, which sometimes involve complicated estimation strategies.

Engel and Hamilton (1990) use a two-state Markov switching univariate model, and find that the movements of three bilateral American dollar rates are characterized by long swings (although the exchange markets seem not to realize this in the sense that the model does not help to explain deviations from uncovered interest parity). They also find that the forecasts of this model are somewhat better than those of the pure random walk. However, Engel (1992) analyzes eighteen exchange rates, including eleven non-dollar rates, and finds that the Markov-switching models does not have superior forecast precision to that of a simple random walk, even though it performs 
better inside the sample. This has become a standard finding; a number of authors have found models which perform well in-sample (e.g., compared with a simple martingale) but which break down in out-of-sample prediction analysis. For instance, Diebold and Nason (1990) use a general non-parametric estimator on a number of different exchange rates. They find that univariate models fit the data much better insample with their estimator than, e.g., a simple random walk, but that the nonparametric estimator does not produce forecasts superior to those of a random walk.1/

Baillie and Bollerslev (1989) find co-integration in a set of American dollar exchange rates; that is, the dollar-yen exchange appears to be co-integrated with e.g., the dollar-DM rate. This finding is quite plausible (and not especially striking) in the context of standard structural exchange rate models, since all bilateral dollar exchange rates can be expected to react similarly to American-specific shocks, for example. However, Diebold, Gardeazabal and Yilmaz (1994) point out that co-integration of bilateral rates implies that, univariate dollar-yen exchange rate forecasts, for example, should be out-performed by incorporating information from the dollar-pound rate (since co-integration implies predictability from the co-integrating relationship). It is therefore all the more striking that Diebold et. al. find no evidence of predictability and co-integration, using the data set of Baillie and Bollerslev. They claim that there is little evidence of common shocks to the movements in dollar exchange rates.

1/ Small-sample problems -- learning and the "peso problem" -- are relevant here; e.g., one might explain Engel and Hamilton in this vein. Other references include Lewis (1989). 


\section{I.D. Summary}

Studies such as Backus (1984), Meese and Rogoff (1983a, 1983b, 1988) and Campbell and Clarida (1987) are typical of the empirical literature that seeks to explain or forecast the monthly or quarterly exchange rate with traditional observable macroeconomic fundamentals, whether based on the monetary or portfolio-balance models. The dispiriting conclusion is that relatively little explanatory power is found, and the models contain little forecasting ability compared to very simple alternatives. Existing structural models have little in their favor beyond theoretical coherence. Positive results, when they are found, are often either fragile, or unconvincing in that they rely on implausible theoretical or empirical models. For these reasons, we, like much of the profession, are doubtful of the value of further time-series modelling of exchange rates at high or medium frequencies using macroeconomic models.

\section{I1. Evidence from across Fixed and Floating Regimes}

It is widely known that real and nominal exchange rates are highly correlated, and that the shocks common to both are highly persistent (e.g., Mark (1990)). These correlations are visible in Figures 1 and 2. To many, the fact that real exchange rate variability went up when nominal variability did after 1973 (also visible in the Figures), suggests that nominal prices are sticky and that monetary disturbances therefore cause both nominal and real exchange rate changes, as in the Dombusch model. Others, such as Stockman $(1987,1988)$, argue that real exchange rate variability is caused by shifts to tastes and technology, and would have gone up after 1973 regardless of the exchange rate regime, which is endogenously chosen in any case. (Real exchange rate variability is surveyed in the chapter of this volume by Froot and Rogoff; regime choice 
is surveyed by Garber and Svensson.) A small recent literature has considered evidence across exchange rate regimes. We now survey this work.

The evidence discussed in Section I above shows that it is difficult to model exchange rate movements in many respects. Nevertheless, exchange rates have one striking empirical feature with which any plausible theory must be consistent: systematically differing volatility. In particular, exchange rates that are officially stabilized show not only low nominal variability, which one would expect virtually by definition, but low real variability as well, compared to those that are allowed to float more or less freely. In the past decade, a number of empirical papers have characterized or exploited these and other regime-specific differences in volatility.

Mussa $(1986,1990)$ convincingly demonstrated that nominal and real exchange rate volatility moved closely together, both being substantially lower during regimes of fixed rates. Persuasive examples include the Canadian experiment with floating in the 1950s, and changes in Ireland's exchange rate regime from a pound to a Deutschemark peg. Eichengreen (1988) provides similar evidence from the interwar period. Mussa reasoned that nominal exchange rate regime-specific differences in real exchange rate volatility could be caused for a variety of reasons, including bubbles, sticky prices, systematically varying macroeconomic shocks, or regime-specific differences in policy behavior.

The subsequent literature has corroborated Mussa's findings regarding real exchange rate volatility, and examined differences in macroeconomic behavior to discover the source of the finding. For instance, Baxter and Stockman (1989) looked at the behavior of a variety of macroeconomic variables across different types of exchange rate regimes, arguing, as had Mussa, that most theories of the open economy imply economic behavior which varies systematically with the nominal exchange rate regime. Baxter and Stockman examined a number of real macroeconomic variables (including 
consumption, output, and trade flows, de-trended in two ways) over forty industrialized and developing countries. While non-theoretical in nature, their results are striking and intuitive. The only systematic regime-specific pattern in the data is higher volatility of the real exchange rate in regimes of floating rates. By way of contrast, the volatility of, for example, output and consumption does not appear to vary systematically with the exchange rate regime.

A similar tactic has been used by Flood and Rose (1993) to study monetary models of exchange rate determination (with both flexible and sticky prices). They rewrite the structural form of the simple monetary model with flexible prices as

$$
e_{1}-\alpha\left(i-i^{*}\right)_{1}=\left(m-m^{*}\right)_{t}-\beta\left(y-y^{*}\right)_{1}-\left(\epsilon-\epsilon^{*}\right)_{3},
$$

and note that both the left- and the right-hand side variables can be measured or estimated. Their analysis hinges on the fact that the volatility of the left-hand side variable during a regime of floating is between three and nine times as volatile as during a fixed exchange rate regime. However, the right-hand side has approximately comparable volatility in fixed and flexible exchange rate regimes. (Both facts are consistent with Figures 1 through 2.) The more general point is that the volatility of macroeconomic variables such as money, output, and prices (appropriately parameterized) does not vary much across exchange rate regimes, certainly not enough to rationalize the large cross-regime differences in exchange rate volatility. Since few macroeconomic variables have regime-specific volatility, they interpret this to mean that macroeconomic variables cannot be very important determinants of exchange rate volatility. This point transcends the narrow confines of the flexible-price monetary model, since different macroeconomic theories of exchange rate determination (e.g., models with sticky prices) merely change the right-hand side of equation (4') from one 
set of macroeconomic components to another. There appears to be a growing general consensus for this conclusion, since it is the rule rather than the exception that large movements in exchange rates occur in the absence of plausible or detectable macroeconomic events. In the two minutes that the average reader has taken to read this page, the dollar/yen exchange rate may well have fluctuated 5 basis points!

The strength of this work is that it characterizes a wide range of currencies and exchange arrangements, and does not rely on sensitive statistical techniques. The evidence convincingly shows that the nominal exchange rate regime is systematically and substantially associated with differences in real exchange rate volatility. This evidence is inconsistent with a large class of models which predict "nominal exchange rate neutrality." This insight is deceptively simple, yet empirically potent. It is quite general, since many theories of the open economy imply that the behavior of such variables as, e.g., money, inflation, and output vary with the exchange rate regime. Differences in economic behavior are especially plausible since the exchange rate regime is chosen by the monetary authorities deliberately.

Instead of looking across regimes of fixed and floating exchange rate regimes, one can also look across regimes of tranquility and turbulence. Hyperinflations represent one of the most interesting types of economic turbulence from the vieupoint of an exchange rate analyst. Monetary theories of exchange rates work substantially better in hyperinflations than in periods of low inflation inflation, in that they can explain the trend in the nominal exchange rate. The classic work is by Frenkel $(1976,1980)$. The impression that variation in the real exchange rate is lower in hyperinflations than in normal times is not correct, however.1/

1/ See, e.g., Davutyan and Pippenger (1985) and Krugman (1978). 
To sum up, there are substantial differences in nominal and real exchange rate behavior across exchange rate regimes which do not appear in observable macroeconomic variables. There are two possible reasons for this. The first is that unobservable macroeconomic shocks affect the exchange rate. The second is that bubbles, defined as exchange rate movements that are unrelated to fundamentals, are the cause of regime-varying exchange rate volatility.

\section{Speculative Bubbles}

Sections I and II suggest that the case for macroeconomic determinants of exchange rates is in a sorry state. With the exception of some significance in tests of statistical innovations and announcements at very short horizons, and some hazy predictive power at long horizons, there is little support for the standard macroeconomic models. Negative findings such as Meese and Rogoff (1983a, 1983b), Campbell and Clarida (1987), and Flood and Rose (1993) suggest more than a failure of specific models of exchange rate determination or typical econometric difficulties. Instead, such results indicate that no model based on such standard fundamentals like money supplies, real income, interest rates, inflation rates and current account balances will ever succeed in explaining or predicting a high percentage of the variation in the exchange rate, at least at short- or medium-term frequencies.

As noted, two broad possibilities remain. The "equilibrium theory" of exchange rates asserts that real exchange rate movements have their roots in real fundamental determinants such as productivity shocks and changes in tastes, even if these factors are unobservable to the econometrician. The alternative theory is that speculative bubbles exist which affect nominal and real exchange rates. A number of pieces of evidence point us away from the equilibrium theory. 
First, the observed pattern of co-movement of exchange rates and interest rates, documented in Section 1, contradicts the equilibrium view.1/ Second, direct evidence on goods prices such as Engel (1993), covered in the chapter by Froot and Rogoff, suggests price stickiness. Third, and most convincingly, the cross-regime evidence reviewed in Section II shows little support for the conclusion that exchange rate variability is caused by shocks to tastes and technology. No macroeconomic variable other than the exchange rate demonstrates regime-varying volatility; there is little indirect confirmation of regime-varying unobservable shocks from other parts of the economy.

The alternative is the possibility of speculative bubbles, i.e., exchange rate movements that are not based in fundamentals, but rather are based in self-confirming expectations. We now turn to this possibility.

In the theoretical literature, a rational speculative bubble is simply the additional indeterminate term that appears in the solution to a differential or difference equation representing a rational-expectations equilibrium to equation (7). These bubbles arise both in monetary models (e.g., Mussa (1976) or Dornbusch (1976b)) and portfoliobalance models (e.g., Rodriguez (1980)), although Obstfeld and Rogoff (1983) have sought to rule out bubbles on a priori grounds.

If we could be confident of the fundamentals part of the equation, we could test for the presence of the additional bubble term in (7). Flood and Garber (1980) introduced a test for a deterministic speculative bubble, that is, one that never bursts once it gets started. Rational speculative bubbles were made stochastic by Blanchard (1979) and Dornbusch (1982). Several researchers have sought to introduce tests for stochastic bubbles in the foreign exchange market, to see if variability is higher than

1/ E.g., Engel and Frankel (1984a), Hardouvelis (1988), and Eichenbaum and Evans (1993), Baxter (1984), and Clarida and Galli (1994). 
can be explained by macroeconomic fundamentals. These tests are closely related to so-called volatility tests, and are surveyed in Frankel and Meese (1987). They have in common that their usefulness is sharply limited by the prerequisite that one already knows how to model fundamentals.

Meese (1986) uses a conventional monetary approach to define fundamentals and a Hausman-style specification test to test for bubbles; he finds some evidence of exchange rate bubbles.1/ Evans (1986) has produced evidence of bubbles in the pound/dollar exchange rate in the early 1980s, based upon a non-parametric test for systematic deviations from uncovered interest parity. Evans' work is distinguished by its careful treatment of the issue of potential data mining, which is accounted for by simulation analysis of different aspects of his test procedure. However, Flood and Hodrick (1990) argue that there is an observational equivalence between expectations of process-switching and bubbles. This problem, in addition to the fact that any test for bubbles is based upon a posited model of fundamentals (an especially important problem in the exchange rate context, given the serious specification difficulties which plague structural exchange rate models) lead Flood and Hodrick to contend that there is little convincing evidence of bubbles in exchange rates.

It is unfortunate but true that these tests cannot help us choose between the bubble hypothesis and the hypothesis of unknown or unobservable fundamentals as maintained by the equilibrium theorists. Nevertheless, the fact that exchange rate variation cannot be explained with any existing model of fundamentals is certainly intuitively consistent with the existence of bubbles, especially when coupled with the cross-regime evidence.

1/ A related test, in the context of the German hyperinflation, is Casella (1989). 
However, if one is to conclude that speculative bubbles are important in exchange rate determination, this still leaves us with a rather unsatisfying conclusion. Rational speculative bubbles are completely indeterminate. It would be nice if economists could say something more specific about what gets bubbles started or what causes them to burst, and perhaps also why large bubbles appear to exist in floating rather than fixed exchange rate regimes. This leads us to the subject of the microstructure of the foreign exchange market, and the possibility of endogenous speculative bubbles.

\section{The Micro Evidence on the Foreign Exchange Market}

To repeat a central fact of life, there is remarkably little evidence that macroeconomic variables have consistent strong effects on floating exchange rates, except during extraordinary circumstances such as hyperinflations. Such negative findings have lead the profession to a certain degree of pessimism vis-a-vis exchange rate research.

We are somewhat more optimistic about the course of future research in international finance, in part because of the prospect of new developments that analyze the market for foreign exchange primarily from a microeconomic perspective. This "market microstructure" approach represents a radical departure from the traditional modelling strategy of treating foreign exchange rates as a macroeconomic relative price. The microeconomic approach to the foreign exchanges is at least potentially consistent with well-known regularities in the data. For example, the volume of transactions in foreign exchange markets is very large. The April 1992 surveys conducted by the Federal Reserve, Bank of England and Bank of Japan found that daily trading totaled $\$ 623$ billion in New York, London and Tokyo combined, up from 
$\$ 430$ billion a day in April 1989. (The global total, including other locations as well, is considerably higher.) It is difficult to rationalize the well-known high gross (but low net) volume of trading on foreign exchange markets without some microeconomic modelling, particularly attention to heterogeneity in the forecasts of market participants. It is far too early to say whether this research agenda will be successful; but the beginnings look promising.

\section{IV.A. The Formation of Expectations}

Expectations of future exchange rate changes are a key determinant of asset demands, and therefore of the current exchange rate. The expectations variable is relatively straightforward in the conventional monetary models: in theoretical terms it is determined by the rational expectations assumption, while in empirical terms it is typically measured by the forward discount or interest differential. The standard empirical implementation of rational expectations methodology infers ex ante expectations of investors from ex post changes in the exchange rate. (This is a particularly attractive way to measure investors' forecasts in the portfolio-balance model, where expectations cannot be measured from the forward market because of a possible exchange risk premium.) However, we may wish to consider a possible failure of the rational expectations methodology, for example due to learning, or peso problems arising from infrequent sudden changes in the exchange rate, as are likely in models like those with speculative bubbles. In this case, we need direct measures of expectations.

\section{IV.A.1. Are Expectations Stabilizing or Destabilizing? Survey Data}


One of the things we would like to know about expectations is whether they are stabilizing or destabilizing. Expectations can be described as stabilizing when the effect of an appreciation today -- relative to some long-run path or mean -- is to induce market participants to forecast depreciation in the future. If investors act on such expectations, they will seek to sell the currency, thereby dampening the original appreciation. This is the stabilizing speculation that Friedman (1953) argued would thrive under floating rates. Expectations can be described as destabilizing, on the other hand, when the effect of an appreciation is to induce market participants to forecast more appreciation in the future. If investors act on such expectations, they will seek to buy the currency, thereby exaggerating the original appreciation. This "bandwagon behavior" can create speculative bubbles. The question then becomes whether expectations are in fact formed in a stabilizing or destabilizing manner. (This question is independent of the perennial question of whether expectations are rational, covered in Lewis's chapter.)

The forward rate cannot be used to measure expectations if one does not feel able a priori to rule out the importance of risk. A new data source has been used to shed light on such questions: the results of surveys of market participants conducted by financial services firms.1/ Much of the new literature on survey data has been surveyed by Takagi (1991).

1/ These data have also been used for other purposes. One purpose is testing rational expectations: Dominguez (1986); McDonald (1990); Liu and Maddala (1992); Chinn and Frankel (1994). Another purpose is studying the behavior of the risk premium: Froot and Frankel (1989); Macbonald and Torrance (1988b, 1990); Cavaglia, Nieuwland, Verschoor, and Wolff (1993); Cavaglia, Verschoor, and Wolff (1993a); Frankel and Chinn (1993). The earlier part of this literature has been surveyed by Froot and Thaler (1990) and Hodrick (1988). The survey data have also been used in studies of announcement effects and foreign exchange intervention, discussed in Sections I.B.2.b and I.B.1.c of this paper, respectively. 
Frankel and Froot (1987a) found that investors tended to react to current appreciations by expecting future depreciations, consistent with either regressive expectations, adaptive expectations, or distributed-lag expectations, at horizons of one year, six months, or three months. In other words, expectations appeared to be stabilizing.1/ Subsequent studies, however, indicated that investors at shorter horizons of one week to one month tend to extrapolate recent trends: Frankel and Froot (1987b, 1990a), Froot and Ito (1989) and Ito (1994). Expectations at these short horizons appear destabilizing. Since most trading in the foreign exchange market is known to consist of taking and unwinding positions at horizons measured in hours rather than months or years, these findings have potentially serious implications.

Most of the survey services that furnish data for these tests are conducted at either the short horizons or the long horizons, but not both. This raises the possibility that different types of market participants form expectations in different ways, and that some are more heavily represented at the short horizons (call them speculators) and others at the long horizons (call them investors). The distinction between speculators and investors is one of several motivations for departing from the assumption that all participants share the same expectations, which until recently was universally made in the field, and to focus on heterogeneity.

\section{IV.A.2, Heterogeneous Expectations}

Some of these articles acknowledge that survey respondents exhibit diverse opinions, even though a measure of central tendency (usually the median) is typically used to measure "the" expectation. More recent papers have explicitly pursued the heterogeneity of expectations, in two ways. One approach is to look for different

1/ Also Cavaglia, Verschoor and Wolff (1993b). 
patterns of expectation formation among different classes of actors. The other approach looks for a relationship between the dispersion of opinion and other microstructure variables of interest, such as the volume of trade in the market.

Ito (1990) and MacDonald (1992) have access to dis-aggregated data on survey responses. Ito examines systematic differences in the behavior of Japanese respondents, distinguished by function such as banker, trader, corporate economist, etc.. He finds evidence of "wishful thinking": Japanese exporters forecast a depreciation of the yen, and importers an appreciation. MacDonald looks at differences in the behavior of corporate respondents residing in seven major countries. He finds more evidence of extrapolative behavior among German respondents than in other countries.

The brute fact of expectations heterogeneity, regardless of the cause, has implications for the foreign exchange market. A high dispersion of expectations should lead to a high volume of trade. Indeed, in the absence of some sort of heterogeneity, it is hard to see why investors trade at all. Frankel and Froot (1990b) look at dispersion in the survey data, and find that it is related to a measure of the volume of trade as well as to market volatility.

\section{IV.A.3. Technical Analysis}

Frankel and Froot $(1986,1990 \mathrm{a}, \mathrm{b})$ reported that "technical analysis" became increasingly prevalent in the exchange rate forecasting business during the first half of the 1980s. Similarly, Taylor and Allen (1992) conducted a questionnaire survey on the use of technical analysis in the London foreign exchange in 1988. At least 90 per cent of respondents reported placing some weight on technical analysis, with the proportion rising steadily with the shortness of the horizon. These short-horizon technical analysts bear a striking resemblance to the infamous destabilizing speculators of classical financial mythology. 
Schulmeister (1987) offered a description of the various rules of technical analysis that are in widest use, and calculated that all of the rules would have made money over the period 1973-86. Goodman (1979) also found that the forecasts of technical analysis performed relatively well as did Levich and Thomas (1993), although Blake, Beenstock, and Brasse (1986) found the reverse.

Most of the rules of technical analysis seem to fit into the category of destabilizing behavior, such as the "momentum" models that call for buying when the current price exceeds the price that held, for example, five days ago. The rules are clearly more complicated than simple extrapolation, however, and in some cases may not be destabilizing at all.1/ Garber and Spencer (1994) argue that the use of dynamic hedging programs by portfolio managers have been destabilizing in recent episodes. Of related interest is the paper by De Grauwe and Decupere (1992), which finds significant evidence of psychological barriers at round numbers in the yen/dollar market: exchange rates tend to resist movements towards numbers such as 130 or 140 yen to the dollar, but to accelerate away from them once the barriers have been crossed. Krugman and Miller (1993) have considered the implications of stop-loss orders for exchange rate determination. Work like this may allow for much more progress in the future.

\section{IV.A.4. Models of Chartists. Fundamentalists and Noise Traders}

A number of researchers have deviated from the rational expectations paradigm to sketch what might be called theories of endogenous speculative bubbles. They typically start from the proposition that market participants' forecasts are drawn from competing views, including for example both technical analysis and economic

\footnotetext{
1/ Allen and Taylor (1989).
} 
fundamentals. From there they attempt to build models of exchange rate determination.

Relevant studies include Goodhart (1988), Frankel and Froot (1986, 1990a), Cutler, Poterba and Summers (1990), De Long, Shleifer, Summers and Waldmann (1990) and Goldberg and Frydman (1993a, b).1/ In such models, changes in the weights assigned by the market to the competing models can themselves alter asset demands and give rise to changes in the exchange rate. DeGrauwe and Dewachter (1990) show that the interaction of chartists and fundamentalists can give rise to an exchange rate process characterized by chaos: a process that is essentially unpredictable, despite the fact that the underlying model is deterministic.

This area of research is quite small. However, it is potentially important, since it is the part of the market microstructure work that is concerned with some of the most central issues of international finance, such as excess volatility and exchange rate determination. We hope for further developments.

\section{IV.B. Trading}

The tremendous level and growth in the volume of trading, particularly in the New York, London, and Tokyo foreign exchange markets, has been documented in statistics collected by central banks every three years. An important question is: Who does all this trading? Typically, a very high fraction of these transactions are reported to take place among banks; less than five per cent involve importers, exporters or other non-financial companies.2/ Traders at most banks take large positions for a few

1/ The implications of a mixture of noise traders and regressive expectations for the question of systematic differences in rates of return on currencies are considered in Evans and Lewis (1992).

2/ E.g., Frankel and Froot (1990b). 
hours, but limit their overnight positions sharply, or close them out altogether.1/ Recently, new players such as hedge funds and other institutional investors have become more important.2/ Much of the work on market microstructure has analyzed the process and characteristics of trading on foreign exchange markets; we now survey that literature.

\section{IV.B.1. The Nature of Trading and Volatility}

The market micro-structure literature bas been successful in uncovering a number of trading regularities in the data. For instance there is evidence of "time deformation."

\section{IV.B.1.a. Time-Varying Volatility. Trading Volume, and Location}

Goodhart and Giugale (1993) and Wasserfallen and Zimmerman (1985) have observed systematic patterns to intra-day volatility. They find that volatility is smaller during intervals when trading volume is known to be smaller, such as over the weekend and over the lunch hour, and is especially large during the first hour of Monday trading for each currency in its own market (i.e., in the domestic country), even when markets in other time zones have opened earlier. Such findings suggest either that residents have a comparative advantage at processing news regarding their own currencies, or else that trading is in some sense largely unrelated to news, perhaps even that trading activity per se generates volatility. Of related interest is Batten and Bhar (1993), who explore the observed statistical relationship between trading volume and price changes,

1/ Fieleke (1981).

2/ Hedge funds manage portfolios for a small number of relatively large individual investors. They deal heavily in derivatives, but the implication of the name is the reverse of the truth: they speculate rather than hedge. On the topic of the new institutional investors, see International Monetary Fund (1993). 
in yen futures markets in three locations. They find, contrary to their expectations, that the relationship does not depend on the size of the market, and they suspect an asymmetry in the role of information flows emanating from the U.S. and Japan.

Many econometricians have observed that exchange rate volatilities change over time. The ARCH model (AutoRegressive Conditional Heteroskedasticity) has become a very popular way of addressing time-varying variances. Bollerslev, Chou and Kroner (1992) offer a general survey. The pattern of time-varying variances matters for the statistical properties of econometric tests of all sorts of propositions, such as those covered in this survey. The pattern matters particularly when investor behovior is thought to depend on perceived uncertainty, as in the literature on time-varying risk premiums surveyed by Frankel (1988) and the chapter by Lewis. Here we consider only the evidence relevant to microstructure.

Engle, Ito and Lin $(1990,1992)$ examine intra-day yen/dollar volatility in four markets: Europe, New York, Pacific, and Tokyo. They find that upswings in volatility in one market are passed on as higher volatility to the next market, an ARCH pattern that they describe by analogy with a global meteor shower and interpret as evidence of information processing. Baillie and Bollerslev (1991) also find evidence of the meteor shower in hourly data on four exchange rates. In each case they also find evidence of increased volatility occurring around the opening and closing of each of the three major world markets, London, New York, and Tokyo. There also appears to be a correlation of intra-day patterns in volatility and volume (e.g., high at the opening and closings of markets). The question becomes whether high volume and volatility reflect the efficient processing of information regarding fundamentals, or something else (such as noise trading).

Jorion (1994) seeks to test one important microstructure theory. The theory says that the correlation between trading volume and volatility should be positive when the 
source of trading volume is disagreement (heterogeneity of beliefs), but the correlation should be negative when volume is determined by the number of traders, due to averaging over larger numbers (liquidity) should reduce variability. He finds support for the theory, in that the variance is observed to depend negatively on a time trend intended to reflect the growing number of traders, and otherwise to depend positively on volume. He uses options prices to obtain an implicit measure of the anticipated component of the variance, rather than the usual $\mathrm{ARCH}$ approach.

\section{IV.B.1.b. The Bid-Ask Spread. Volatility and Volume}

Jorion also looks at the bid-ask spread, the standard measure of transactions costs. He confirms earlier findings (Glassman, 1987, and Bessembinder, 1993) that the spread widens before weekends and holidays, supporting the liquidity effect. He also confirms earlier findings that the bid-ask spread depends positively on the variance, but negatively on volume. He and Wei (1994) use the option-implied volatility for this purpose. Glassman, (1987), Boothe (1988), Bollerslev and Domowitz (1993), Bollerslev and Melvin (1994), and Lee (1994), use GARCH models of the variance in their tests of the effect on the bid-ask spread.

The presumption here is that information is processed efficiently. At a time when beliefs are particularly heterogenous and therefore trading volume is particularly high, the presumption is that the market is responding to a rapid generation of information.

Hsieh and Kleidon (1994) cast some doubt on the proposition that information is processed efficiently. Their point of departure is a model by Admati and Pfleiderer. It features a crucial distinction between well-informed traders and liquidity traders. Some of the iquidity traders have some discretion as to when they trade, and so seek to trade at a time when high volume drives down the cost of transaction. (This is the liquidity effect on the bid-ask spread.) Hsieh and Kleidon confirm the correlation of volume 
and volatility that the Admati-Pfleiderer model is designed to explain: there is a bunching of volume and volatility at both the open and the close in the foreign exchange market.

A deeper look uncovers serious problems, however. First, the bid-ask spread is observed to go wp, not down, at the open and close, contradicting the notion that liquidity traders are deliberately bunching at these times to save on transactions costs. Second, at the close in London, when volume and volatility are high in that market, there is no detectible simultaneous effect in the open New York market. This seems to contradict existing models of asymmetric information, which presuppose a common knowledge of economic structure despite the existence of idiosyncratic information. If volatility is high in London because information relevant to the pound/dollar rate is coming out, then why shouldn't the same effect show up in the pound/dollar rate in the New York market?

Hsieh and Kleidon think that the answer lies in models where information is aggregated imperfectly and inventories are important. They take at their word traders who explain that at morning open, they need to get a "feel" for the market by trading, thus explaining the combination of high trading volume, high volatility and high spreads in the morning. Towards evening close, traders are anxious to unload excess inventories, explaining the reappearance of the heightened volume, volatility and spreads.

\section{IV.B.2. The Behavior of Market-Makers}

In equity markets, research into microstructure has explored such questions as whether the existence and behavior of "market-makers" responsible for market clearing 
makes a difference. Several researchers have begun to extend this exploration of microstructure to the foreign exchange market.

The foreign exchange market is a "decentralized, quote-driven dealership market" (Lyons, 1993). In other words, it is a phone-and-computer network over which dealers (both traders at banks, who can take open positions, and brokers who do not) quote bid and offer prices, and then consummate transactions. These communications are purely bilateral, so that the prices and quantities traded are not transparent as they are in other financial markets.

Lyons (1991) is a first cut at a microstructural perspective. It models customer order flow as the source of information asymmetry among dealers. The configuration of the market can lead to an externality in the processing of information. To the extent that dealers have market power and are risk averse, their trading behavior will not result in prices that reveal all information fully. The main result is that the greater the market power and risk-aversion of dealers, the less revealing are prices.

Lyons (1993) investigates these issues using a data set on five days in the life of a single market-maker, containing the time-stamped transaction prices and quantities in the New York mark-dollar market.1/ Earlier high-frequency data, e.g., Goodhart's 13 weeks of "indicative quotes" obtained from the Reuters screen, did not include actual

1/ More specifically, the data set consists of time-stamped inter-dealer quotes and trades, the market-maker's indirect (brokered) trades, and the time-stamped prices and quantities for transactions mediated by a broker. 
order flow or transaction prices.1/ Lyons finds evidence of two different channels whereby trading volume generates movements in the bid and offer rates quoted by individual dealers: the inventory-control channel; and the information channel.

Inventory costs create incentives for market-makers to change prices so as to control their positions. However, if some traders have better information than others, it is also rational for market-makers to adjust their own beliefs, and price quotes, in response to order flow.

Lyons (1994) uses the same data set to test an additional effect on the transactions price: the effect of the quantity traded. He seeks to shed light on two competing theories of why trading volume is sometimes very high. What he calls the "event uncertainty" view is that high trading volume indicates that information is being processed rapidly. What he calls the "Hot Potato" theory is that high trading volume indicates that little information is being processed. Rather, "liquidity-trader" customers are placing orders with their traders, who then unload their over-extended positions on other traders, who continue to pass the exposure like a hot potato (consistent with the Admati-Pfleiderer model of discretionary liquidity traders tested by Hsieh and Kleidon). The evidence supports the Hot-Potato view: the quantity traded has a

1/ Goodhart and Figliuoli (1991). Goodhart, Ito and Payne (1994) suggest that a good deal of skepticism is warranted regarding such "indicative quotes, "i.e., the bid and ask quotes that are posted to all potential customers. Traders usually set better prices when they transact with each other. Goodhart, Ito and Payne use data from a new trading system, the Reuters 2000-2, to compare actual transactions prices [via this new electronic broker] with the indicative quotes $($ "FXFX"). They find that movements in the two are very close, so that for some purposes either series can be used. But the behavior of the margin between the highest bid price and the lowest ask price, known in the UK as the "touch," in the Reuters 2000-2 data is quite different from the behavior of the spread between the FXFX bid and ask quotes. In the first case the two prices are both firm and they are normally input by different banks; in the second the quotes are both indicative and they are always from the same bank. In other words, one should not mistake the publicly posted bid and ask prices for the prices at which foreign exchange traders trade with each other. Fortunately, Lyons' $(1993,1994)$ data set constitutes direct observation of trader behavior. It shows that actual median interdealer spreads are smaller still, as compared to Goodhart's sort of spreads. 
significant effect only when the time between transactions is long. When the time between transactions is short, the quantity traded has no significant effect on the trader's prices, suggesting that the trader views these orders as coming from liquidity traders rather than informed traders.

\section{IV.C. An Early Assessment of the Market Micro-Stnucture Literature}

The foreign exchange research on market microstructure is newborn. It has a long way to go before it can claim to produce a model of exchange rate determination. After realistic models of dealer behavior are constructed, the desirable next step is to let such dealers interact in the market place, in order to derive a central tendency to the torrent of bid and offer quotes and transaction prices in which each individual deals. That central tendency would be what in macroeconomic models we call "the" market-clearing exchange rate. Then the interaction among dealers needs to be imbedded in the larger universe of borrowers, lenders, importers and exporters, who play a role in the foreign exchange market, so that economic fundamentals can ultimately be brought back in. Such a strategy might lead to models of endogenous speculative bubbles that could account for some of the problematic empirical findings reviewed in this survey, especially if such bubbles could be more easily formed in regimes of flexible exchange rates.

This said, the market microstructure literature is a long way from achieving these goals. Much has been learned about volatility, volume, and bid-ask spreads, from the studies described in section IV.B; little as yet about central issues like the sources and persistence of heterogeneous beliefs, excess volatility, and exchange rate determination. The macroeconomic literature on exchange rates has not provided the right answers. 
But we believe it does have the right questions. Research like that described in section IV.A might turn out to point the right direction.

\section{V.Conclusion: Endogenous Speculative Bubbles?}

Although the evidence of Meese and Rogoff and others on the failure of the standard models based on monetary fundamentals to predict at short horizons still holds, there is more reason at longer horizons to pay attention to some of the models, such as the Dornbusch overshooting theory. Three independent strands of research are consistent with the hypothesis that the exchange rate may move in the direction suggested by the Dornbusch model, but in an inertia-laden manner that is inconsistent with the standard rational expectations approach. The hypothesis can be described as "overshooting the overshooting equilibrium."

The three strands are as follows. (1) Tests of bias in the forward market show a persistent pattern whereby the exchange rate not only (on average) fails to move in line with the predictions of the forward discount or interest differential, but actually moves in the opposite direction. Neither those who interpret the forward discount bias as a risk premium nor those who interpret it as a systematic prediction error have been able to explain convincingly why the correlation with the forward discount should be negative.

(2) Some researchers claim an ability for fundamentals models to pick the direction of movement, relative to the current spot rate, especially at longer horizons. As noted in section I.C.1 above, Woo (1986), Somanath (1986), Mark (1992) and a number of others claim, essentially, that a convex combination of the monetary model and the lagged spot rate can outperform the lagged spot rate. The robustness of such results can never be taken for granted. Long data sets are needed for a definitive 
evaluation. Nevertheless, there is some reason to think that, notwithstanding puzzling short-run dynamics that are observed in the foreign exchange markets, the models win out in the end.1/

(3) As explained in section I.B.2, unexpected changes in monetary policy do in fact frequently cause movements in the exchange rate in the direction hypothesized by the sticky-price monetary model. For example, news of contractionary American monetary policy that raises interest rates is associated with dollar appreciation. There is some reason, however, to believe that the instantaneous reaction is less than the medium-term reaction, i.e., that the exchange rate tends subsequently to continue to move in the same direction, notwithstanding that this finding is inconsistent with rational expectations. For instance, Eichenbaum and Evans (1993) find that it takes an estimated two years for the exchange rate to undergo the full reaction to an unexpected change in monetary policy. Clarida and Gali, 1994, also find a lag before the peak effect.

The Eichenbaum-Evans pattern, if it is confirmed in subsequent research, would explain the longstanding puzzle regarding the forward discount bias, the first item listed above: the dollar appreciates gradually in the aftermath of an increase in the interest differential, rather than contemporaneously as the rational-expectations form of the overshooting model (or of any other model) says it should. An interval during which the interest differential is high is thus an interval during which the currency is likely to be appreciating, rather than depreciating. This would explain why the interest

1) There is an analogy with the tests of the proposition whether the real exchange rate follows a raridom walk, against the alternative of a slow return toward a long-run equilibrium. It is by now widely accepted that the slow return to equilibrium is there, but the power of unit root tests in twenty years of data is very low and so one needs a century of data to find it (or a cross-section). 
differential or forward discount on average points in the wrong direction. The question then becomes: Why does the currency appreciate gradually, rather than suddenly?

The rudiments of a theory of endogenous speculative bubbles, and therefore an answer to the question, may lie in the microstructure of the foreign exchange markets. Such a theory must contain three elements: (i) a role for fundamentals that puts an eventual limit on the extent to which a speculative bubble can carry the market away from equilibrium, so that fundamentals win out in the long run, (ii) something like a combination of risk-aversion and model uncertainty (as suggested by the existing heterogeneity of forecasting techniques) that in the short-run is capable of breaking the usual rational-expectations arbitrage linking the exchange rate to its long-run equilibrium, and (iii) some short-run dynamics that arise from the trading process itself (e.g., noise trading that generates volatility which swamps macro fundamentals on a short-term basis). These three elements could be described, respectively, as (i) the eventual bursting of speculative bubbles, (ii) the potential for speculative bubbles, (iii) the endogenous genesis and prolongation of speculative bubbles. We are hopeful that more will be accomplished on these research frontiers soon. 


\section{References}

Allen, Helen and Mark Taylor (1989) "Chartists, Noise and Fundamentals: A Study of the London Foreign Exchange Market" CEPR Paper no. 341.

Allen, Polly and Peter Kenen. 1980. Asset Markets, Exchange Rates, and Economic Integration. New York: Cambridge University Press.

Backus, David (1984) "Empirical Models of the Exchange Rate: Separating the Wheat from the Chaff" Canadian Joumal of Economics XVII-4, 824-846.

Baillie, Richard, and Tim Bollerslev (1989) "Common Stochastic Trends in a System of Exchange Rates," Journal of Finance 44, 167-181.

Baillie, Richard, and Tim Bollerslev (1991) "Intra-day and Inter-market Volatility in Foreign Exchange Rates," Review of Economic Studies, 58, 565-585.

Batten, Jonathan, and Ram Bhar (1993) "Volume and Price Volatility in Yen Futures Markets: Within and Across Three Different Exchanges" Working Paper No. 93-15. Centre for Japanese Economic Studies, Macquarie University, Sydney.

Baxter, Marianne, and Alan C. Stockman (1989) "Business Cycles and the Exchange Rate System" Journal of Monetary Economics 23, 377-400.

Beck, Stacie (1993) "The Ricardian Equivalence Proposition: Evidence from Foreign Exchange Markets," Journal of International Money and Finance 12, no.2, 154-169.

Bessembinder, H. (1993) "Bid-Ask Spreads in the Interbank Foreing Exchange Markets," Joumal of Financial Economics, forthcoming.

Bilson, John (1978), "The Monetary Approach to the Exchange Rate -- Some Empirical Evidence" IMF Staff Papers, 25 (March): 48-75. 
Black, Stanley (1973) "International money markets and flexible exchange rates" Studies in International Finance 25, Princeton, NJ: Princeton University.

Black, Stanley, and Michael Salemi (1988) "FIML Estimation of the DollarDeutschemark Risk Premium in a Portfolio Model," Joumal of Intemational Economics $25,205 \cdot 224$.

Blanco, Herminio and Peter M. Garber (1986) "Recurrent Devaluations and Speculative Attacks on the Mexican Peso" Joumal of Political Economy 94, 148-166.

Blake, D., M. Beenstock and V. Brasse (1986) "The Performance of UK Exchange Rate Forecasters" The Economic Joumal, December, 986-999.

Blanchard, Olivier (1979) "Speculative bubbles, crashes and rational expectations," Economic Letters: $387-89$.

Blundell-Wignall, Adrian, and F. Browne (1991) "Increasing financial market integration: Real exchange rates and macroeconomic adjustment" OECD working paper.

Bollerslev, Tim, Ray Chou and Kenneth Kroner (1992), "ARCH Modeling in Finance," Joumal of Econometrics 52, 5-59.

Bollerslev, Tim, and lan Domowitz (1993) "Trading Patterns and Prices in the Interbank Foreign Exchange Market," Joumal of Finance 48, 1421-1443.

Bollerslev, Tim, and Michael Melvin (1994) "Bid-ask Spreads and Volatility in the Foreign Exchange Market: An Empirical Analysis," Joumal of Intemational Economics.

Boothe, Paul (1988) "Exchange Rate Risk and the Bid-Ask Spread: A Seven-Country Comparison," Economic Inquiry 26, 485-492.

Boothe, Paul and Debra Glassman (1987) "The Statistical Distribution of Exchange Rates" Joumal of Intemational Economics 22, 153-67. 
Boughton, James (1988) "The Monetary Approach to Exchange Rates: What Now Remains?" Essays in International Finance, no. 171, Princeton, NJ: Princeton University.

Bovenberg, A. Lans (1989) "The Effects of Capital Income Taxation on International Competitiveness and Trade Flows," American Economic Review 79. no.5, Dec., 1045-64.

Branson, William (1977) "Asset Markets and Relative Prices in Exchange Rate Determination" Sozialwissenschafiliche Annalen 1, 69-89.

---- (1983) "Macroeconomic Determinants of Real Exchange Risks," in R.J.Herring, ed., Managing Foreign Exchange Risk, Cambridge, UK, Cambridge University Press.

..-.-, and Dale Henderson (1985) "International Asset Markets: Specification and Influence," in R. Jones and P. Kenen, eds., Handbook of International Economics. Amsterdam: North-Holland.

..-.-., Hannu Halttunen, and Paul Masson (1977) "Exchange Rates in the Short-Run: The Dollar-Deutschemark rate" European Economic Review 10, 303-24.

...-., ....., and -.-.- (1979) "Exchange Rates in the Short-Run: Some Further Results" European Economic Review 12, 395-402.

Buiter, Willem, and Marcus Miller (1982), "Real Exchange Rate Overshooting and the Output Cost of Bringing Down Inflation," European Economic Review 18, May/June, 85-123.

Calvo, Guillermo and Carlos Rodriguez (1977) "A Model of Exchange Rate Determination Under Currency Substitution and Rational Expectations" Journal of Political Economy 85, 3 (June): 617-26.

Campbell, John and Richard Clarida (1987) "The dollar and real interest rates," Carnegie-Rochester Conference on Public Policy 27 (August). 
Casella, Alessandra (1989) "Testing for Rational Bubbles with Exogenous or Endogenous Fundamentals: The German Hyperinflation Once More," Joumal of Monetary Economics, July.

Catte, P., G. Galli, and S. Rebecchini (1994) "Concerted Interventions and the Dollar: An Analysis of Daily Data," Ossola Memorial Conference, Banca d'Italia, Perugia, Italy; forthcoming in a volume edited by F. Papadia and F. Saccomani.

Cavaglia, Stefano, Frederick Nieuwland, Willem Verschoor, and Christian Wolff (1993), "On the Biasedness of Forward Foreign Exchange Rates: Irrationality or Risk Premia?," Limburg Institute of Financial Economics, The Netherlands, Sept. 1993, forthcoming Joumal of Business.

Cavaglia, Stefano, Willem Verschoor, and Christian Wolff (1993a), "Asian Exchange Rate Expectations," Joumal of the Japanese and Intermational Economies 7, 57-77.

Cavaglia, Stefano, Willem Verschoor, and Christian Wolff (1993b), "Further Evidence on Exchange Rate Expectations" Joumal of Intemational Money and Finance 12, 78-98.

Chen, Zhaohui (1992) "Cointegration and Exchange Rate Forecasting: A State Space Model," LSE, United Kingdom.

Chinn, Menzie, and Jeffrey Frankel (1994), "Patterns in Exchange Rate Forecasts for 25 Currencies," Joumal of Money, Credit and Banking, 26, no.5, November.

Chinn, Menzie and Richard A. Meese (1992) "Banking on Currency Forecasts" U.C. Santa Cruz working paper.

Clarida, Richard and Jordi Galli (1994) "Sources of Real Exchange Rate Fluctuations: How Important Are Nominal Shocks?" NBER working paper No. 4658, Feb. In Camegie-Rochester Conference on Public Policy, forthcoming. 
Copeland, Laurence (1989) "Exchange Rates and News: A Vector Autoregression Approach," in R. MacDonald and M. Taylor, eds., Exchange Rates and Open Economy Macroeconomics, Oxford, UK, and Cambridge, MA, Basil Blackwell, 218-238.

Cornell, Bradford (1982) "Money Supply Announcements, Interest Rates, and Foreign Exchange" Joumal of Intemational Money and Finance, 1, no.2 (August), 201-08.

Davutyan, N. and J. Pippenger (1985) "Purchasing Power Parity did not Collapse during the 1970s," American Economic Review, 75, 5, December, 1151-1158.

De Grauwe, Paul and Danny Decupere (1992) "Psychological Barriers in the Foreign Exchange Market," Centre for Economic Policy Research Discussion Paper No. 621, January.

DeGrauwe, Paul, and Hans Dewachter (1990), "A Chaotic Monetary Model of The Exchange Rate," Centre for Economic Policy Research Discussion Paper No. 466, Oct.

De Long, J. Bradford, Andrei Shleifer, Lawrence Summers and Robert Waldmann (1990) "Noise Trader Risk in Financial Markets" Joumal of Political Economy 98-4, 703. 38.

Diebold, Francis X., and James Nason (1990) "Nonlinear Exchange Rate Prediction?" Joumal of Intemational Economics 28, 315-332.

....., Steven Husted, and Mark Rush (1991) "Real Exchange Rates Under the Gold Standard" Joumal of Political Economy 99, 1252-1271.

-...-, Javier Gardeazabal and Kamil Yilmaz (1994) "On Co-integration and Exchange Rate Dynamics", Joumal of Finance 49: 727-735.

Dominguez, Kathryn (1986), "Are Foreign Exchange Forecasts Rational? New Evidence From Survey Data, ${ }^{2}$ Economics Letters 21: 277-82. 
54

..... (1990) "Market Responses to Coordinated Central Bank Intervention," CamegieRochester Series on Public Policy, vol. 32.

....- (1992) "The Informational Role of Official Foreign Exchange Intervention Operations: The Signalling Hypothesis," Chapter 2 in Exchange Rate Efficiency and the Behavior of Intemational Asset Markets, Garland Publishing Company, N.Y.

Dominguez, Kathryn M. and Jeffrey A. Frankel (1993a) "Does Foreign Exchange Intervention Matter? Disentangling the Portfolio and Expectation Effects, " NBER Working Paper No. 3299, abridged versions in American Economic Review 83, December 1993, and in J.Frankel, On Exchange Rates (Cambridge: MTT Press).

and ..... (1993b) Does Foreign Exchange Intervention Work? (Washington, Institute for International Economics).

Dooley, Michael and Peter Isard (1982a) "A portfolio-balance rational-expectations model of the dollar-mark rate." Joumal of Intemational Economics 12 (May): 257-76.

....- and -...- (1982b) "The Role of the Current Account in Exchange Rate Determination: A Comment on Rodriguez," Joumal of Political Economy 90, 6, December, 1291-1294.

..... and -.... (1983) "The portfolio-balance model of exchange rates and some structural estimates of the risk premium." IMF Staff Papers 30 (December): 683-702.

..... and ..... (1987), "Country Preferences, Currency Values and Policy Issues," Joumal of Policy Modeling, Spring.

and -.... (1991) "A Note on Fiscal Policy, Investment Location Decisions, and Exchange Rates," Joumal of Intemational Money and Finance 10 no.1, March, 161-168.

..... , ..... and Mark Taylor (1992) "Exchange Rates, Country Preferences, and Gold," NBER Working Paper No. 4183, October. 
Dornbusch, Rudiger (1976a) "Expectations and Exchange Rate Dynamics" Joumal of Political Economy 84, 1161-1176.

.... (1976b) "The Theory of Flexible Exchange Rate Regimes and Macroeconomic Policy," Scandinavian Joumal of Economics 78, 255-275.

(1978) "Monetary Policy under Exchange Rate Flexibility" in Managed Exchange Rate Flexibility, Federal Reserve Bank of Boston Conference Series.

-..- (1980) "Exchange Rate Economics: Where do We Stand?" Brookings Papers on Economic Activity 1, 143-94.

-.-. (1982) "Equilibrium and disequilibrium exchange rates," Zeitschrift fur Wirtschaftsund Sozialwissenshaften 102, 6: 573-99. [Reprinted in Dornbusch, R. Dollars, Debts, and Deficits. Cambridge, Mass.: MIT Press.]

.... (1987) "Flexible exchange rates 1986" Economic Joumal 1: 1-18.

Driskill, Robert (1981) "Exchange Rate Dynamics: An Empirical Investigation." Joumal of Political Economy 89, 2 (April): 357-71.

-.--., Nelson Mark, and Steven Sheffrin (1992) "Some Evidence in Favor of A Monetary Rational Expectations Model with Imperfect Capital Substitutability," Intemational Economic Review 33, 223-238.

Edison, Hali (1993) "The Effectiveness of Central Bank Intervention: A Survey of the Post-1982 Literature," Essays in Intemational Finance, Princeton, NJ: Princeton University.

Edison, Hali, and B. Dianne Pauls (1993) "A Re-assessment of the Relationship Between Real Exchange Rates and Real Interest Rates: 1974-1990" Joumal of Monetary Economics 31, 165-187. 
Edwards, Sebastian (1982) "Exchange Rates and News: A Multi-Currency Approach," Joumal of Intemational Money and Finance 1, 211-224.

...- (1983) "Floating Exchange Rates, Expectations and New Information" Joumal of Monetary Economics 11, 321-336.

Eichenbaum, Martin, and Charles Evans (1993) "Some Empirical Evidence on the Effects of Monetary Policy Shocks on Exchange Rates," NBER Working Paper No. 4271.

Eichengreen, Barry (1988) "Real Exchange Rate Behavior Under Alternative International Monetary Regimes: Interwar Evidence," European Economic Review 32, 363-371.

Eijffinger, Sylvester C.W. and Noud P.D. Gruijters (1991) "On the Effectiveness of Daily Interventions by the Deutsche Bundesbank and the Federal Reserve System in the U.S. Dollar/ Deutsche Mark Exchange Market," Tilburg University, Research Memorandum FEW394, Tilburg 1989. Forthcoming in E. Baltensperger and H.W. Sinn (eds.) Exchange Rate Regimes and Currency Union, London:

Engel, Charles M. (1992) "Can the Markov Switching Model Forecast Exchange Rates?" NBER Working Paper No. 4210.

and Jeffrey Frankel (1984a) "Why Interest Rates React to Money Announcements: An Answer from the Foreign Exchange Market" Joumal of Monetary Economics 13, 31 9. and Jeffrey Frankel (1984b)"The Secular Inflation Term in Open-Economy Phillips Curves: A Comment on Flood," European Economic Review 24.

..... and James D. Hamilton (1990) "Long Swings in the Dollar" American Economic Review 80, 689-713. 
..... and Anthony Rodriguez (1989) "Tests of International CAPM with Time-Varying Covariances" Joumal of Applied Econometrics, 119-38.

Engle, Robert, Takatoshi Ito, and Wen-Ling Lin (1990) "Meteor Showers or Heat Waves? Heteroskedastic Intra Daily Volatility in the Foreign Exchange Market," Econometrica 58, 525-542.

...-., ....-, and -.... (1992) "Where Does the Meteor Shower Come From? The Role of Stochastic Policy Coordination," Joumal of International Economics 32, 221-240.

Evans, George W. (1986) "A Test for Speculative Bubbles in the Sterling-Dollar Exchange Rate" American Economic Review 76, 621-636.

Evans, Martin and Karen Lewis (1992) "Peso Problems and Heterogeneous Trading: Evidence from Excess Returns in Foreign Exchange and Euromarkets" NBER Working Paper no. 4003, Feb., p.16-19.

Fieleke, Norman (1981) "Foreign-Currency Positioning by U.S. Firms: Some New Evidence," Review of Economics and Statistics LXIII, no.1, Feb. 35-42.

Finn, Mary G. (1986) "Forecasting the Exchange Rate" Journal of International Money and Finance 5, 181-193.

Flood, Robert A. and Peter Garber (1980) "Market fundamentals versus price-level bubbles: The first tests." Joumal of Political Economy 88 (August): 745-70.

..... and ..... (1983) "A Model of Stochastic Process Switching" Econometrica 51, 537. 552.

..... and ..... (1991) "The Linkage Between Speculative Attack and Target Zone Models of Exchange Rates" Quarterty Joumal of Economics 106, 1367-1372.

..... and Robert J. Hodrick (1990) "On Testing for Speculative Bubbles" The Joumal of Economic Perspectives 4-2, 85-101. 
...-., and Andrew K. Rose (1993) "Fixing Exchange Rates" NBER Working Paper 4503.

-..-.., ...., and Donald J. Mathieson (1991) "An Empirical Exploration of Exchange

Rate Target Zones" Carnegie Rochester Conference Series on Public Policy 35, 7-65.

Frankel, Jeffrey A. (1979) "On the Mark: A Theory of Floating Exchange Rates Based on Real Interest Differentials," American Economic Review 69, no. 4 (Sept.), 601-622.

-..- (1982) "In Search of the Exchange Risk Premium: A Six-Currency Test Assuming Mean-Variance Optimization," Joumal of International Money and Finance 1,

(December): 255-74.

-.-.- (1988) "Recent Estimates of Time-Variation in the Conditional Variance and in the Exchange Risk Premium," Joumal of International Money and Finance, 7 (March), 115-125.

-.-. (1993) "Monetary and Portfolio-balance Models of the Determination of Exchange Rates" in J.Frankel, On Exchange Rates (Cambridge: MIT Press). [Revised version of "Monetary and Portfolio-Balance Models of Exchange Rate Determination" in J. Bhandari, ed., Economic Interdependence and Flexible Exchange Rates. Cambridge, Mass.: MIT Press, 1983.]

Frankel, Jeffrey, and Menzie Chinn (1993), "Exchange Rate Expectations and the Risk Premium: Tests for a Cross-Section of 17 Currencies" Review of International Economics 1, no.2 (June), 136-144.

Frankel, Jeffrey, and Kenneth A. Froot (1986) "Understanding the U.S. Dollar in the Eighties: The Expectations of Chartists and Fundamentalists" Economic Record, 24-38. Reprinted in On Exchange Rates (Cambridge: MIT Press), 1993.

....- and -..-- (1987a) "Short-Term and Long-Term Expectations of the Yen/Dollar Exchange Rate: Evidence from Survey Data" Joumal of the Japanese and International Economies 1, 249-74. 
-.-- and --.-- (1987b) "Using Survey Data to Test Standard Propositions Regarding Exchange Rate Expectations" American Economic Review, 77, no. 1 (March), 133-153. [Reprinted in Exchange Rate Economics, vol. II, edited by R.MacDonald and M.Taylor, International Library of Critical Writings in Economics, Edward Elgar Publishing, U.K., 1992.]

-... and -..- (1990a) "Chartists, Fundamentalists, and the Demand for Dollars" in Anthony Courakis and Mark Taylor, eds., Private Behavior and Government Policy in Interdependent Economies. Oxford: Clarendon Press.

..... and -...- (1990b) "Exchange Rate Forecasting Techniques, Survey Data, and Implications for the Foreign Exchange Market." NBER Working Paper no. 3470. Abridged versions in American Economic Review 80, 2, 181-5, and On Exchange Rates, 1993.

----- and Gikas Hardouvelis (1985) "Commodity Prices, Money Surprises, and Fed Credibility" Journal of Money, Credit and Banking 17-4 I, 427-38.

---- and Richard A. Meese (1987) "Are Exchange Rates Excessively Variable?" NBER Macroeconomics Annual 2, 117-153.

Frenkel, Jacob A. (1976) "A Monetary Approach to the Exchange Rate: Doctrinal Aspects and Empirical Evidence" Scandinavian Joumal of Economics 78 (May), 200224. Reprinted in J. Frenkel and H. G. Johnson, eds., The Economics of Exchange Rates. Reading, Mass.: Addison-Wesley, 1978, 97-116.

....- (1980) Exchange rates, prices and money: Lessons from the 1920s. American Economic Review 70, 2 (May): 235-42.

-....- (1981) "Flexible Exchange Rates, Prices and the Role of 'News'" Joumal of Political Economy 89-4, 665-705. Reprinted in J. Bhandari, and B. Putnam, eds. Economic Interdependence and Flexible Exchange Rates, Cambridge, Mass., MTT Press, 1983. 
60

and H. G. Johnson (1978), eds., The Economics of Exchange Rates. Reading, Mass.: Addison-Wesley.

Friedman, Milton (1953) "The Case for Flexible Exchange Rates" in Essays in Positive Economics (University of Chicago, Chicago).

Froot, Kenneth and Jeffrey Frankel (1989), "Forward Discount Bias: Is It an Exchange Risk Premium?" Quarterly Jaumal of Economics 104, 416 (February): 139-61; reprinted in Advances in Behavioral Finance, R.Thaler, ed., Russell Sage Foundation, New York, 1993.

Froot, Kenneth A. and Takatoshi Ito (1989) "On the Consistency of Short-Run and Long-Run Exchange Rate Expectations" Joumal of International Money and Finance 8 , no. $4,487-510$.

and Richard Thaler (1990) "Anomalies: Foreign Exchange," Joumal of Economic Perspectives 4, June, 179-192.

----- and Maurice Obstfeld (1991) "Exchange-Rate Dynamics Under Stochastic Regime Shifts" Joumal of International Economics 31, 203-229.

Girton, Lance and Dale Henderson (1977) "Central Bank Operations in Foreign and Domestic Assets under Fixed and Flexible Exchange Rates" in P. Clark, D. Logue, and R. Sweeney, eds., The Effects of Exchange Rate Adjustment (Department of the Treasury, Washington, D.C.) 151-79.

Glassman, Debra (1987) "Exchange Rate Risk and Transactions Costs: Evidence from Bid-Ask Spreads" Joumal of International Money and Finance 6, 479-490.

Goldberg, Michael, and Roman Frydman (1993) "Theories Consistent Expectations and Exchange Rate Dynamics," forthcoming in H.Frisch and A. Worgoter, eds., OpenEconomy Macroeconomics (London: MacMillan Publishing). 
Goldberg, Michael, and Roman Frydman (1993b) "Qualitative Rationality and Behavior in the Foreign Exchange market," NYU Economics Department mimeo.

Golub, Stephen (1989) "Foreign-Currency Government Debt, Asset Markets, and the Balance of Payments" Joumal of Intemational Money and Finance 8, no. 2, 285-94.

Goodhart, Charles (1988) "The Foreign Exchange Market: A Random Walk with a Dragging Anchor" Economica 55, 437-60.

-.--- and L. Figliuoli (1991) "Every Minute Counts in Financial Markets," Joumal of International Money and Finance 10, 23-52.

..... and M. Giugale (1993) "From Hour to Hour in the Foreign Exchange Market," LSE FMG Discussion Paper No. 33. In The Manchester School, 61, no. 1 (March): 134.

...-., Takatoshi Ito, and R. Payne (1994), "One Day in June, 1993: A Study of the Working of Reuters 2000-2 Electronic Foreign Exchange Trading System," Bank of Italy, Perugia, Italy, July. In The Microstructure of Foreign Exchange Markets, J. Frankel, G. Galli and A. Giovannini, eds., University of Chicago Press, Chicago, forthcoming.

Goodman, S. (1979) "Foreign Exchange Forecasting Techniques: Implications for Business and Policy" Joumal of Finance 34, 415-27.

Grilli, Vittorio, and Nouriel Roubini (1993) "Liquidity and Exchange Rates: Puzzling Evidence from the G-7 Countries," mimeo.

Hansen, Lars Peter and Robert J. Hodrick (1980) "Forward Exchange Rates as Optimal Predictors of Future Spot Rates" Joumal of Political Economy 88-5, 829-853.

Hardouvelis, Gikas (1988) "Economic News, Exchange Rates, and Interest Rates Joumal of International Money and Finance 7, 23-5. 
62

Haynes, Steven, and Joe Stone (1981) "On the Mark: Comment," American Economic Review 71 (December): 1060-67.

Henderson, Dale, and Stephanie Sampson (1983) "Intervention in Foreign Exchange Markets: A Summary of Ten Staff Studies," Federal Reserve Bulletin 69, 830-36.

Henderson, Dale (1984) "Exchange Market Intervention Operations: Their Role in Financial Policy and Their Effects," in Exchange Rate Theory and Practice, J.Bilson and R.Marston, eds., Chicago: University of Chicago Press.

Henderson, Dale, Deborah Danker, Richard Haas, Steve Symansky, and Ralph Tryon, (1987), "Small Empirical Models of Exchange Market Intervention: Applications to Germany, Japan and Canada," Joumal of Policy Modeling, Spring, 143-173

Hodrick, Robert (1978) "An empirical analysis of the monetary approach to the determination of the exchange rate" in J. Frenkel and H. G. Johnson, eds., The Economics of Exchange Rates. Reading, Mass.: Addison-Wesley, 97-116.

Hodrick, Robert (1988) The Empirical Evidence on the Efficiency of Forward and Futures Foreign Exchange Markets. In Fundamentals of Pure and Applied Economics. Chur, Switzerland: Harwood Academic Publishers.

Hogan, Ked, Michael Melvin, and Dan Roberts (1991) "Trade Balance News and Exchange Rates: Is There a Policy Signal?" Joumal of Intemational Money and Finance 10, S90-S99.

Hsieh, David (1989) "Testing for Nonlinear Dependence in Daily Foreign Exchange Rates" Joumal of Business 62, 339-368.

Hsieh, David, and Allan Kleidon (1994) "Bid-ask Spreads in Foreign Exchange Markets: Implications for Models of Asymmetric Information, "Bank of Italy, Perugia, Italy, July. In The Microstructure of Foreign Exchange Markets, J. Frankel, G. Galli and A. Giovannini, eds., University of Chicago Press, Chicago, forthcoming. 
Isard, Peter (1983) "An accounting framework and some issues for modeling how exchange rates respond to the news," in Jacob Frenkel, ed., Exchange Rates and Intemational Macroeconomics. Chicago: University of Chicago Press.

Ito, Takatoshi (1990) "Foreign Exchange Rate Expectations: Micro Survey Data" American Economic Review 80, 3, June, 434-49.

...- (1994) "Short-Run and Long-Run Expectations of the Yen/Dollar Exchange Rate," Joumal of the Japanese and Intemational Economies 8, no. 2, June: 119-143.

...-- and V. Vance Roley (1987) "News from the U.S. and Japan: Which Moves the Yen/Dollar Exchange Rate" Joumal of Monetary Economics 19, 255-277.

..... and ..... (1990) "Intraday Yen/dollar Exchange Rate Movements: News or Noise?" Joumal of Intermational Financial Markets, Institutions and Money 1, no.1.

Jones, Ronald and Peter B. Kenen (1985) Handbook of International Economics (Amsterdam, North-Holland).

Jorion, Philippe, (1994) "Risk and Turnover in the Foreign Exchange Market," Bank of Italy, Perugia, Italy, July. In The Microstnucture of Foreign Exchange Markets, J. Frankel, G. Galli and A. Giovannini, eds., University of Chicago Press, Chicago, forthcoming.

Kaminsky, Graciela, and Karen Lewis, (1993) "Does Foreign Exchange Intervention Signal Future Monetary Policy?" NBER Working Paper No. 4298, March.

Kenen, Peter (1988) Managing Exchange Rates, The Royal Institute of International Affairs, Council on Foreign Relations Press, New York.

Klein, Michael (1993) "The Accuracy of Reports of Foreign Exchange Intervention," Joumal of Intemational Money and Finance 12, 6, Dec., 644-653. 
64

..... and E. Rosengren (1991) "What do We Learn From Foreign Exchange Intervention?" Tufts University working paper.

Kouri, Pentti (1976) "The Exchange Rate and the Balance of Payments in the Short Run and in the Long Run: A Monetary Approach" Scandinavian Journal of Economics $78,280-304$.

Krugman, Paul R (1978) "Purchasing Power Parity and Exchange Rates: Another Look at the Evidence" Joumal of International Economics 8, 3 (August): 397-407.

-...- (1979) "A Model of Balance of Payments Crises" Joumal of Money, Credit and Banking 11, 311-325. Reprinted in Currencies and Crises, Cambridge, MA. MIT Press, $1992,61-76$

-.-- (1985) "Is the Strong Dollar Sustainable?" in The U.S. Dollar -- Recent

Developments, Outlook and Policy Options. Federal Reserve Bank of Kansas City. 10333.

-...- (1991) "Target Zones and Exchange Rate Dynamics" Quarterly Joumal of Economics CVI, 669-682.

...- (1993) "Recent Thinking about Exchange Rate Determination and Policy," in The Exchange Rate and the Balance of Payments, edited by Adrian Blundell-Wignall, Sydney, Reserve Bank of Australia: 6-22.

..... and Marcus Miller, eds (1991) Exchange Rate Targets and Currency Bands (Cambridge, Cambridge University Press).

-..- and (1993) "Why Have a Target Zone?" CEPR DP No. 718. Rochester Conferene-Series.

Lee, Tae-Hwy (1994), "Spread and Volatility in Spot and Forward Exchange Rates," Joumal of International Money and Finance 13, no.3, 375-383. 
Levich, Richard, and Lee Thomas (1993) "The Significance of Technical Trading-Rule Profits in the Foreign Exchange Market: A Bootstrap Approach," Joumal of Intemational Money and Finance 12, no.6, 563-586.

Lewis, Karen K. (1988) "Testing the Portfolio Balance Model: A Multi-lateral Approach" Journal of Intemational Economics 7, 273-288.

....- (1989) "Changing Beliefs and Systematic Forecast Errors," American Economic Review 79, 621-636.

-... (1990) "Occasional Interventions to Target Rates" NBER Working Paper No. 3398.

-...- (1993), "Are Foreign Exchange Intervention and Monetary Policy Related and Does it Really Matter?," NBER Working Paper No. 4377, June.

Liu, Peter, and G.S. Maddala (1992) "Rationality of Survey Data and Tests for Market Efficiency in the foreign Exchange Markets," Joumal of Intemational Money and Finance 11, no.4, August, 366-381.

Lucas, Robert E. Jr. (1982) "Interest Rates and Currency Prices in a Two-Country World" Joumal of Monetary Economics. 335-360.

Lyons, Richard (1991) "Information Intermediation in the Microstructure of the Foreign Exchange Market," October, revised version of NBER Working Paper No. 3889.

.... (1993) "Tests of Microstructural Hypotheses in the Foreign Exchange Market," NBER Working Paper No. 4471, September.

.... (1994) "Foreign Exchange Volume: Sound and Fury Signifying Nothing?" Bank of Italy, Perugia, Italy, July. In The Microstructure of Foreign Exchange Markets, J. Fräkel, G. Galli and A. Giovannini, eds., University of Chicago Press, Chicago, forthcoming. 
MacDonald, Ronald (1983), "Some Tests of the Rational Expectations Hypothesis in

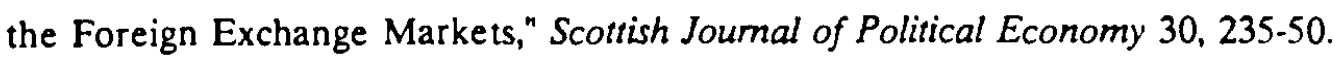

-..- (1990), "Are Exchange Market Forecasters 'Rational': Some Survey-Based Tests," The Manchester School of Economic and Social Studies, LVIII, 229-241.

-... (1990) "Exchange Rate Economics: An Empirical Perspective," in Graham Bird, ed., The Intemational Financial Regime (London and San Diego, Academic Press Lid.), 91-144.

(1992) "Exchange Rate Survey Data: A Disaggregated G-7 Perspective," University of Dundee mimeo.

....- and Mark P. Taylor (1989) "Economic Analysis of Foreign Exchange Markets: An Expository Survey," in MacDonald and Taylor, eds., Exchange Rates and Open Economy Macroeconomics, Oxford, UK, and Cambridge, MA, Basil Blackwell, 1-108.

..... and -...- (1992) "Exchange Rate Economics" International Monetary Fund Staff Papers March, 39-1, 1-57.

..... and -... (1993a) "The Monetary Approach to the Exchange Rate: Rational Expectations, Long-Run Equilibrium, and Forecasting," IMF Staff Papers, 40, March, 89-107.

-.-- and -..-- (1993b) "Exchange Rate Behavior Under Alternative Exchange Rate Arrangements" mimeo.

..... and -...- (1994) "The Monetary Model of the Exchange Rate: Long-Run Relationships, Shor Run Dynamics, and How to Beat a Random Walk," Joumal of International Money and Finance 13, no. 3 (June), 276-290.

and T.S. Torrance (1988a) "Exchange Rates and the News: Some Evidence Using UK Survey Data," The Manchester School, 56, 69-76. 
..... and -.... (1988b) "On Risk, Rationality and Excessive Speculation in the Deutschemark-US Dollar Exchange Market: Some Evidence Using Survey Data," Oxford Bulletin of Economics and Statistics 50, no.2, 107-123.

-.-. and -.... (1990) "Expectations Formation and Risk in Four Foreign Exchange Markets," Oxford Economic Papers 42, no.3, 544-561

Mark, Nelson C. (1990) "Real and Nominal Exchange Rates in the Long Run" Joumal of International Economics 28, 115-136.

.... (1992) "Exchange Rates and Fundamentals" Ohio State University working paper.

McKinnon, Ronald (1976), "Floating Exchange Rates 1973-74: The Emperor's New Clothes," in K. Brunner and A. Meltzer, eds., Institutional Arrangements and the Inflation Problem. Camegie-Rochester Series on Public Policy 3: 79-114.

McKinnon, Ronald (1988) "Monetary and exchange rate policies for international financial stability: A proposal," Joumal of Economic Perspectives 2, 1 (Winter): 83-103.

Meese, Richard A. (1986) "Testing for Bubbles in Exchange Markets" Joumal of Political Economy 94, 345-373.

-.-.- (1990) "Currency Fluctuations in the Post-Bretton Woods Era" Joumal of Economic Perspectives 4-1, 117-134.

....- and Kenneth Rogoff (1983a) "Empirical Exchange Rate Models of the Seventies" Joumal of International Economics 14, 3-24.

-...- and -.... (1983b) The Out-of-Sample Failure of Empirical Exchange Rate Models" in J. Frenkel, ed Exchange Rates and International Macroeconomics (Chicago, University of Chicago Press).

...-. and -..-- (1988) "Was it real? The Exchange Rate - Interest Differential Relationship Over the Modern Floating-rate Period" Joumal of Finance 43-4, 933-948. 
..... and Andrew K. Rose (1991) "An Empirical Assessment of Non-Linearities in Models of Exchange Rate Determination" Review of Economic Studies 58, 603-619.

and Kenneth Singleton (1982) "On Unit Roots and the Empirical Modeling of Exchange Rates," Journal of Finance 37, 1029-1035.

Miller, Marcus, and Paul Weller (1991) "Exchange Rates Bands with Price Inertia" Economic Joumal 101, 1380-1399.

Mundell, Robert. 1964. Exchange rate margins and economic policy. In J. Carter Murphy, ed., Money in the Intemational Order. Dallas.

Mussa, Michael (1976) "The Exchange Rate, the Balance of Payments, and Monetary and Fiscal Policy Under a Regime of Controlled Floating" Scandinavian Joumal of Economics 78, 229-48.

.... (1979) "Empirical Regularities in the Behavior of Exchange Rates and Theories of the Foreign Exchange Market" in Policies for Employment, Prices, and Exchange Rates (eds: Karl Brunner and Allan H. Meltzer, North-Holland, New York), 9-57.

-.-- (1981) The Role of Official Intervention Group of Thirty Occasional Papers, No. 6. New York: Group of Thirty.

-..- (1986) "Nominal Exchange Rate Regimes and the Behavior of the Real Exchange Rate" in Real Business Cycles, Real Exchange Rates and Actual Policies (eds: Karl Brunner and Allan H. Meltzer, North-Holland, New York), 117-213.

....- (1990) "Exchange Rates in Theory and in Reality," Essays in Intemational Finance No.179, Princeton, NJ: Princeton University.

Niehans, Jurg (1975) "Some doubts about the efficacy of monetary policy under flexible exchange rates," Joumal of International Economics 5 (August): 225-81. 
Obstfeld, Maurice (1986) "Balance of Payments Crises and Devaluation" American Economic Review 76-1, 72-81.

(1990), "The Effectiveness of Foreign-Exchange Intervention: Recent Experience: 1985-1988" in International Policy Coordination and Exchange Rate Fluctuations, edited by W. Branson, J. Frenkel, and M. Goldstein, University of Chicago Press, Chicago.

-..- and Kenneth Rogoff (1983) "Speculative hyperinflations in maximizing models: Can we rule them out?" Journal of Political Economy 91 (August): 675-87.

...- and ....- (1984) "Exchange Rate Dynamics with Sluggish Prices under Alternative Price-Adjustment Rules" International Economic Review 25-1, 159-174.

Obstfeld, Maurice and Alan Stockman (1985) "Exchange rate dynamics" in R. Jones and P. Kenen, eds., Handbook of Intemational Economics. Amsterdam: North-Holland.

Papell, David (1988), "Expectations and Exchange Rate Dynamics After a Decade of Floating," Journal of International Economics 25, 303-317.

.... (1989) "Monetary Policy in the United States Under Flexible Exchange Rates," American Economic Review 79, 1106-1116.

[--- (1993) "Cointegration and Exchange Rate Dynamics," University of Houston, March.]

Rodriguez, Carlos (1980) "The Role of Trade Flows in Exchange Rate Determination: A Rational Expectations Approach," Journal of Political Economy 88-6,

Rogoff, Kenneth (1984) "On the Effects of Sterilized Intervention: An Analysis of Weekly Data," Joumal of Monetary Economics 14, 133-150.

---- (1985) "Can exchange rate predictability be achieved without monetary convergence? Evidence from the EMS" European Economic Review 28: 93-115. 
Schinasi, Gary and P.A.V.B. Swamy (1989) "The Out-of-Sample Forecasting Performance of Exchange Rate Models when Coefficients are Allowed to Change" Joumal of International Money and Finance 8, 375-390.

Schulmeister, Stephen (1987) "An Essay on Exchange Rate Dynamics" Research Unit Labor Market and Employment Discussion Paper 87-8, Wissenschaftzentrum Berlin fur Sozialforschung, Berlin.

-... (1988) "Currency Speculation and Dollar Fluctuations," Banca Nazionale del Lavoro Quarterly Review 167, 343-365.

and Michael Goldberg (1989) "Noise Trading and the Efficiency of Financial Markets," in G.Luciani, ed., The American Financial System: Between Euphoria and Crisis Quaderni della Fondazione Adriano Olivetti: Rome, 117-153.

Somanath, V.S. (1986) "Efficient Exchange Rate Forecasts" Joumal of International Money and Finance 5, 195-220.

Stockman, Alan (1980) "A Theory of Exchange Rate Determination," Journal of Political Economy 88, 673-698.

-.-- (1987) "The Equilibrium Approach to Exchange Rates" Federal Reserve Bank of Richmond Economic Review March/April, 12-30.

-..-- (1988) "Real Exchange-Rate Flexibility under Pegged and Floating Exchange-Rate Systems" Camegie-Rochester Conference Series on Public Policy 29, 259-294.

Svensson, Lars E.O. (1992) "An Interpretation of Recent Research on Exchange Rate Target Zone" Joumal of Economic Perspectives 6-4, 103-118.

.... (1993) "Assessing Target Zone Credibility" European Economic Review 37-4, 763793. 
Takagi, Shinji (1991) "Exchange Rate Expectations: A Survey of Survey Studies," IMF Staff Papers 38, 156-183.

Tandon, Kishore, and Thomas Urich (1987) "International Market Response to Announcements of US Macroeconomic Data," Joumal of Intemational Money and Finance, 6, no.1, 71-83.

Taylor, Mark and Helen Allen (1992) The Use of Technical Analysis in the Foreign Exchange Market" Joumal of Intemational Money and Finance, 11, no.3, 304-314.

Throop, Adrian (1993) "A Generalized Uncovered Interest Parity Model of Exchange Rates," FRBSF Economic Review 2, 3-16.

Tryon, Ralph (1983), "Small Empirical Models of Exchange Market Intervention: A Review of the Literature, " Staff Studies no. 134, Board of Governors of the Federal Reserve System: Washington, D.C., September.

Wei, Shang-Jin (1994), "Anticipations of Foreign Exchange Volatility and Bid-Ask Spreads," NBER Working Paper No. 4737, May.

Whitt, Joseph (1992), "Nominal exchange rates and unit roots: A Reconsideration" Joumal of Intemational Money and Finance 11, no.6, Dec., 539-511.

Williamson, John (1985) The Exchange Rate System. Policy Analyses in International Economics No. 5, Institute for International Economics, September 1983. Washington, D.C. Revised 1985.

Williamson, John (1987) "Exchange Rate Management: The Role of Target Zones," American Economic Review 77-2, $200-204$.

Williamson, John and Marcus Miller (1987) Targets and indicators: A blueprint for the international.coordination of economic policy. Policy Analyses in International

Economics no. 22 (September). Institute for International Economics, Washington, D.C. 
72

Wolff, Christian (1987) "Time-Varying Parameters and the Out-of-Sample Forecasting Performance of Structural Exchange Rate Models," Joumal of Business and Economic Statistics Jan. 5, 87-97.

Woo, Wing T. (1985) "The Monetary Approach to Exchange Rate Determination under Rational Expectations" Joumal of International Economics 18, 1-16.

-.- (1987) "Some Evidence of Speculative Bubbles in the Foreign Exchange Markets" Joumal of Money, Credit, and Banking 19, 499-514. 
</ref_section> 